\title{
Possibilities of Applying Soil Herbicides in Fruit Nurseries - Phytotoxicity and Selectivity
}

\author{
Zarya Rankova \\ Fruit-Growing Institute, Plovdiv 4004, 12, Ostromila Str. \\ Bulgaria
}

\section{Introduction}

Fruit-growing is one of the major sub-branches of agriculture in Bulgaria and its development is enhanced by a number of positive prerequisites - favourable soil and climatic conditions, a rich genetic fund of local and introduced cultivars, production experience and national traditions. Production of grafted fruit tree planting material is an important starting point in developing modern fruit-growing. Requirements set by integrated fruit production and the needs of producing certified fruit planting material impose the development of ecologically sound integrated approaches for plant protection, including an efficient control of weed infestation in the fruit nursery, based on selective herbicides without any residual effects, as an element of high agrotechnical practice. In 1991 the European Plant Protection Organization (EPPO) published a scheme for production of certified virus-free fruit trees and rootstocks. The recommendations complying with the scheme of EPPO were included in Directive 92/34 of the Council of the European Economic Community of 28 April 1992 on the marketing of fruit plant propagating materials and fruit plants intended for fruit production. The aim of the Directive was to guarantee the quality of propagating material in the European Union countries after the borders have come down. Certified virus-free fruit planting material could only be produced under the conditions of very high agrotechnical background, including an efficient and ecologically sound control of weed infestation in the fruit nursery.

Weed vegetation is a serious problem in fruit crop nurseries. Weeds strongly suppress the growth of rootstocks and grafted trees in the process of planting material production. A direct damage caused by weed infestation is markedly expressed (weed-crop competition for moisture, light and nutrients from soil and introduced with fertilizers). Under the effect of weeds, growth and development of young trees is delayed, wood does not mature and the planting material obtained is non-standard. The indirect damage caused by weeds (dissemination of pests and diseases, including viral ones) in that case is quite strongly expressed, keeping in mind the modern issues to the production of certified, free of viral diseases fruit planting material.

In scientific literature there are data that a number of weed species could be also attacked by diseases, including viral ones, and thus weeds become the reason for their spread to the cultivated plants. It was established that PPV (plum pox potty virus) casing the economically most important Sharka disease in stone fruit species, could be hosted by a number of weed species contained in the weed association in the fruit nursery (Oosten, 1971; Rankova \& Milusheva, 2001; Milusheva \& Rankova, 2002; Milusheva \& Rankova, 2006) 
Under the conditions of modern fruit production, an efficient and ecologically sound weed control in the fruit nursery could hardly be carried out without a developed scientific chemical control system based on soil-applied and leaf herbicides with proven selectivity for fruit species.

There are data in literature about the different effects of some soil and leaf herbicides on growth of fruit species used as rootstocks - from lack of phytotoxicity and ability to produce good quality rootstocks suitable for grafting, to very strong toxicity after applying some active substances contained in herbicides, causing plant death. The effect of applying some soil herbicides in yellow plum seedling rootstocks was studied (Porterfield et al., 1993; Wazbinska, 1997; Kaufman \& Libek, 2000 a; Kaufman \& Libek, 2000 b; Rankova, 2004), in peach seedling rootstocks (Arenstein, 1980; Kuhns L., 1981; Lange, 1987; Lourens et al., 1989; Jankovic, et al., 1995; Abdul et al., 1998; Rankova, 2002; Rankova, 2004), in wild cherry seedling rootstocks (Crisp et al., 1984;Clay, 1984; Porterfield et al., 1993),in mahaleb (Rankova, 2006); in apricot seedling rootstocks (Arenstein, 1980; Mitchell \& Abernethy, 1989).

The present work provides summarized data from studies carried out in the period 20012009 at the Fruit-Growing Institute - Plovdiv and it has set the aim of presenting the incidence of phytotoxicity and selectivity in some major seedling rootstocks after application of soil herbicides. The effect of a number of soil herbicides (napropamide, pendimethalin, metolachlor, oxyfluorofen, terbacil, linuron, oxadiargyl, etc.) on weed infestation, growth habits and physiological status of different seedling rootstocks for fruit species (yellow plum (Prunus cerasifera, Ehrh., Myrobolan), peach seedling rootstock (Prunus persica L., Batsch), wild cherry (Prunus avium L.), Mahaleb (Prunus mahaleb L.), apricot seedling rootstock (Prunus armeniaca L.), walnut (Juglans regia L.) was studied under the conditions of model pot experiments and field studies. Those seedling rootstocks have been widely used as rootstocks for plum, peach, sweet cherry, apricot, nectarine and walnut fruit cultivars, thanks to their good adaptability to the soil and climatic conditions and their excellent affinity to the range of cultivars grown in Bulgaria.

Probably, the use of the active substance terbacil in the studies will make an impression. After the accession of Bulgaria to the EU, its application was prohibited, despite the results of its excellent herbicide efficiency against a large number of annual grassy and broad-leaved weeds and its use in fruit-bearing orchards and in some nurseries (in rootstocks for apple cultivars and forest species). Although treatment with that soil herbicide is prohibited at present, the results of the carried out investigations showed that it could be applied in fruit tree nurseries for some fruit species (yellow plum, peach), because a depressing effect on the growth of the rootstocks was not reported. The other herbicides included in the study also have a comparatively broad spectrum of herbicide efficiency and persistence in soil for 2-3 months after the date of treatment. Their selection was made with the aim of providing herbicide efficiency during the first months after emergence of the seedlings, when the competition and the suppressing effect of the weed vegetation are most strongly expressed. Only preliminary stratified seeds (stones) were used during the implementation of the experiments for the reliable reporting of the soil herbicide effect on the process of plant emergency.

\section{Model (pot experiments) for studying the effect of the soil herbicides on the vegetative habits of seedling rootstocks}

\subsection{Material and methods}

Stratified seeds (stones) of yellow plum, peach, wild cherry, walnut of Kuklenski cultivar and apricot were planted (by 5 seeds) in pots of volume $1 \mathrm{~kg}$ sand and alluvial-meadow soil 
(Fluvisol), pH 7,2 and content of mobile phosphorus $\mathrm{P}_{2} \mathrm{O}_{5}-21,6 \mathrm{mg} / 100 \mathrm{~g}$ of soil. Treatment with soil herbicides was applied immediately after seeding. Ten variants in five replications were set.

Variants: 1. Control (untreated); 2. Napropamide - Devrinol 4 F - 4,0 1/ha; 3. Pendimethalin - Stomp 33 EC - 4,0 1/ha; 4. Terbacil - Sinbar $80 \mathrm{WP}$ - 1,0 kg/ha; 5. Oxadiargyl - Raft 800 WDG - $250 \mathrm{~g} / \mathrm{ha} ; 6$. Metolachlor - Dual Gold 960 EC - 1,0 1/ha; 7. Isoxaflutole - Merlin 750 WG - $50 \mathrm{~g} /$ ha; 8. Linuron - Afalon 45 SC - 3,0 1/ha; 9. Acetochlor- Trophy- 3,0 1/ha; 10. Oxyfluorofen - Galigan 240 EC - 1,5 1/ha;

The herbicide treatment rates were calculated according to the area of the cultivation vessel. The experimental plants were grown for 60 days under controlled conditions (temperature of $20-25^{\circ} \mathrm{C}$ and relative air humidity $65-70 \%$ ) in a glass-and-steel green house. During that period observations were made on seedling emergence, development and external symptoms of phytotoxicity. At the end of the period the following biometric indices were reported: stem height $(\mathrm{cm})$ and above-ground mass (stem + leaves) - in average per plant (g). The results obtained were statistically processed following the standard methods.

\subsection{Results and discussion}

\subsubsection{Effect of soil herbicides on the vegetative habits of yellow plum seedlings}

The applied soil herbicides had a different effect on the emergence and development of yellow plum seedlings. No differences in the rate of seedling emergence were observed after treatment with napropamide (Devrinol $4 \mathrm{~F}-4,0$ l/ha) and terbacil (Sinbar $80 \mathrm{WP}-1,0$ $\mathrm{kg} / \mathrm{ha}$ ). When treated with oxadiargyl (Raft $800 \mathrm{WG}-250 \mathrm{~g} / \mathrm{ha}$ ), the plants emerged at the same time with those of the control, however shortly after that symptoms of necrosis appeared on the cotyledons and the plants died about 10 days after emergence. Only single plants survived but white chlorosis developed on their leaves - the tissues around the central vein, and slight necrosis appeared at the leaf margins. Plant growth was suppressed. The last to emerge (up to the 20th day after the emergence of the control seeds) were the plants treated with pendimethalin (Stomp 33 EC - 4,0 1/ha), (Var. 3). Their development was delayed and they had much shorter stems (rosettes) and smaller leaves (Fig. 1).

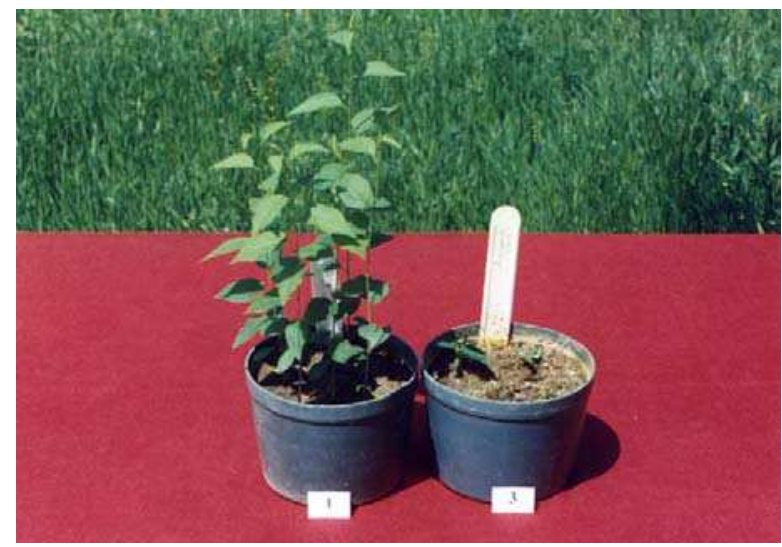

Fig. 1. Inhibiting effect of pendimethalin in yellow plum seedlings under sand culture conditions. 
External symptoms of toxicity and growth suppression were not reported for the seedlings of the variants treated with napropamide and terbacil.

The plants treated with isoxaflutole (Merlin $750 \mathrm{WG}-50 \mathrm{~g} / \mathrm{ha}$ ) emerged at the same time with those of the control. Later their development was delayed, strongly expressed chlorosis appeared, the tissues about the central vein whitened (white chlorosis), a large number of the plants withered (Fig. 2). Again only single plants continued to develop in that variant.

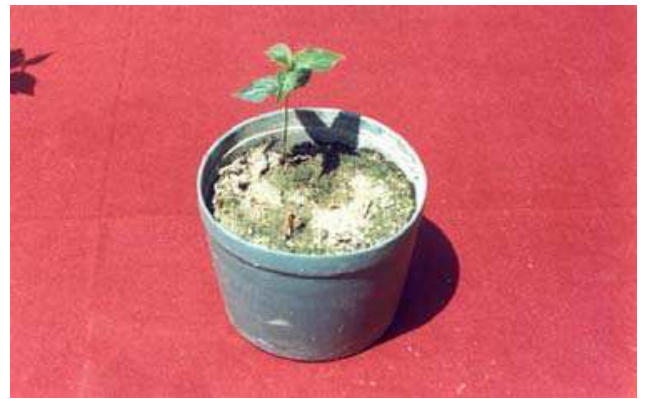

Fig. 2. White chlorosis on the leaves of yellow plum after treatment with isoxaflutole (Merlin $750 \mathrm{WG})$.

The seedlings treated with metolachlor, linuron, acetochlor and oxyfluorofen emerged at the same time with the control plants but later their development was delayed and until the $20^{\text {th }}$ day after emergence withering and dying of the plants was observed.

The least depressing effect on growth was exerted by the active substances napropamide and terbacil - Variants 2 and 4 (Fig. 3 and 4). After treatment of the seedlings with oxadiargyl - Raft 800 WG - 250 g/ha (Var. 5) a suppression of stem development was observed. The lowest values of both biometric characteristics were established after treatment with pendimethalin - Stomp 33 EC - 4,0 1/ha (Var. 3). The differences to the controlled variant were statistically highly significant.

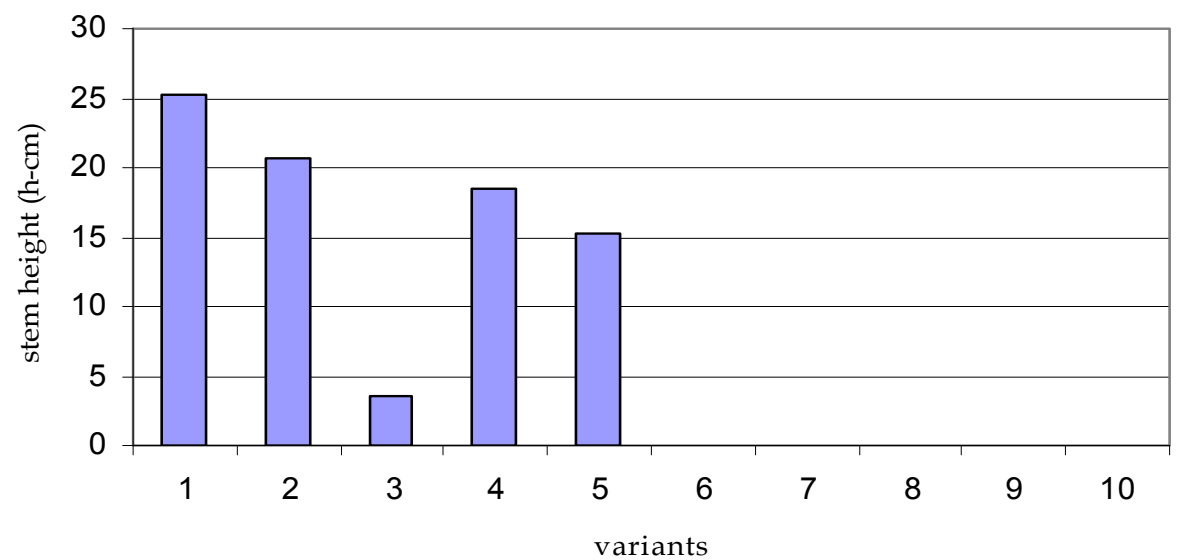

LSD 5\%-0.87, 1\%-1.27, 0.1\%-1.90

Fig. 3. Stem height of yellow plum seedlings after treatment with soil herbicides $(\mathrm{h}-\mathrm{cm})$. 


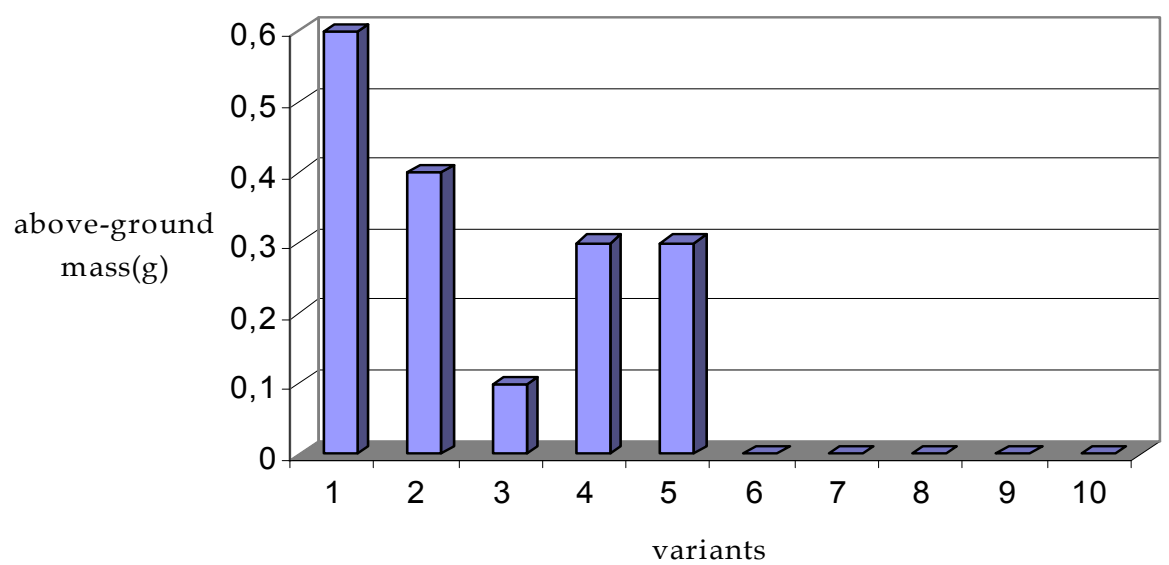

LSD 5\%-0.13, 1\%-1.20, 0.1\%-1.29

Fig. 4. Effect of soil herbicides on the above-ground mass of yellow plum seedlings (g).

The strong inhibiting effect of pendimethalin under sand culture conditions could be explained by the physical basis of the herbicide selectivity and the possibility to induce phytotoxicity on light soils (sand) and in direct contact with the germinating seeds (stones). The results obtained about the effect of the studied soil-applied herbicides on the vegetative habits of yellow plum seedlings under sand culture conditions gave the grounds to draw the following conclusions: 1 . After treatment with napropamide and terbacil, toxicity was not observed and the growth habits of the plants were close to the untreated control; 2 . Strongly suppressing effect was established after treatment with pendimethalin under sand culture conditions; 3. Strong phytotoxicity expressed in dying of the plants was reported after treatment with metolachlor, linuron, acetochlor and oxyfluorofen.

\subsubsection{Effect of soil herbicides on the vegetative habits of peach seedlings}

The obtained results showed that the applied herbicide active substances had a different effect on seedling development compared to sand culture. The plants of the variants treated with napropamide (Var. 2), pendimethalin (Var. 3), terbacil (Var. 4), oxadiargyl (Var. 8) and isoxaflutole (Var. 9) emerged at the same time as those of the control. They grew well without external symptoms of phytotoxicity. Later, in Variant 7 (Merlin 750 WG $-5 \mathrm{~g} / \mathrm{da}$ ) white chlorosis emerged along the leaf vein. The plants of the variants treated with metolachlor (Dual Gold 960 EC 1,0 l/ha), linuron (Afalon $50 \mathrm{WP}$ - 3,0 l/ha), acetochlor (Trophy - 3,0 1/ha) and oxyfluorofen (Galigan 240 EC - 3,0 1/ha) emerged later than those of the control. When applying metolachlor (Var. 6) only single plants emerged and their growth was suppressed. Leaf withering and plant dying was observed until the $20^{\text {th }}$ day after emergence. Analogous habits were established in the seedlings of Variant 8 (linuron Afalon 50 WP - 3,0 1/ha), Variant 9 (acetochlor - Trophy - 3,0 1/ha) and Variant 10 (oxyfluorofen - Galigan 240 EC - 3,0 1/ha).

Single seeds emerged in the variants treated with linuron and acetochlor and their growth was strongly suppressed. Withering from the leaf tip was observed and the plants died until the $20^{\text {th }}$ day after emergence. Phytotoxicity was also established in the plants treated with 
oxyfluorofen (Var. 10). The seedlings emerged later than those of the control. Later their growth was delayed, chlorosis appeared at the leaf margins, turning into necrosis and causing plant death in 20 - 25 days after emergence.

The slightest effect on the experimental plants was exerted by the active substances terbacil and pendimethalin (Fig. 5). Out of all the reported biometric characteristics, values closest to the control plants were established in the plants of Variant 4 - terbacil - Sinbar $80 \mathrm{WP}-1,0$ $\mathrm{kg} / \mathrm{ha}$, followed by Variant 3 - pendimethalin - Stomp $33 \mathrm{EC}-3,0$ 1/ ha.

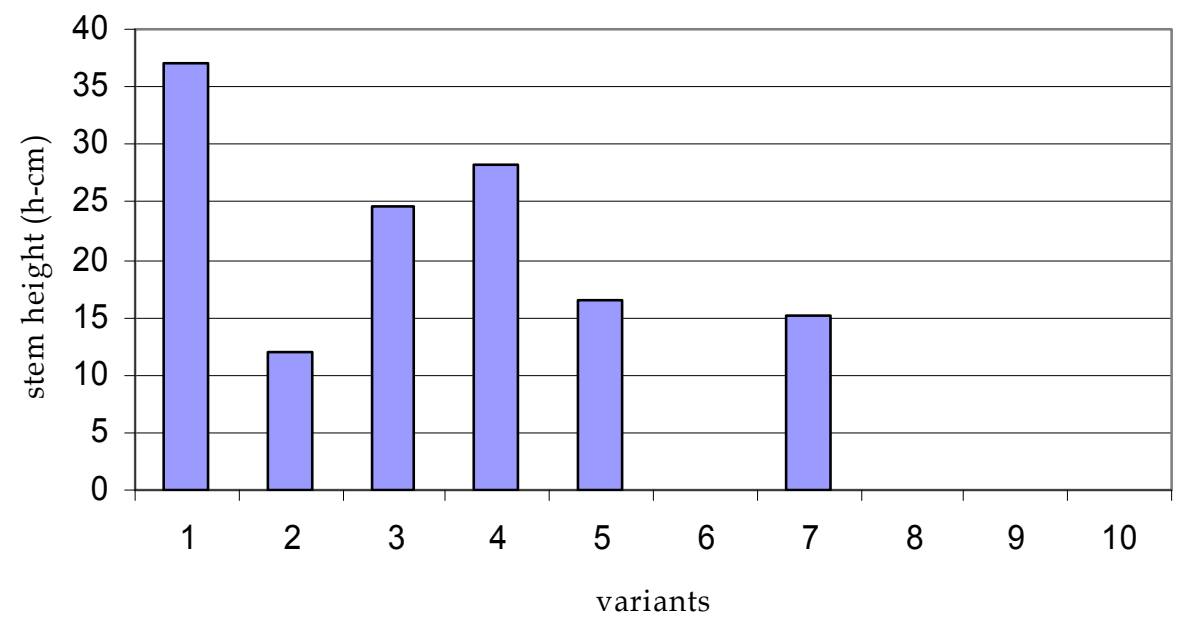

LSD $_{5 \%}-1,98,1 \%-2,65,0.1 \%-3,58$

Fig. 5. Effect of soil herbicides on stem height of peach seedlings (h-cm)

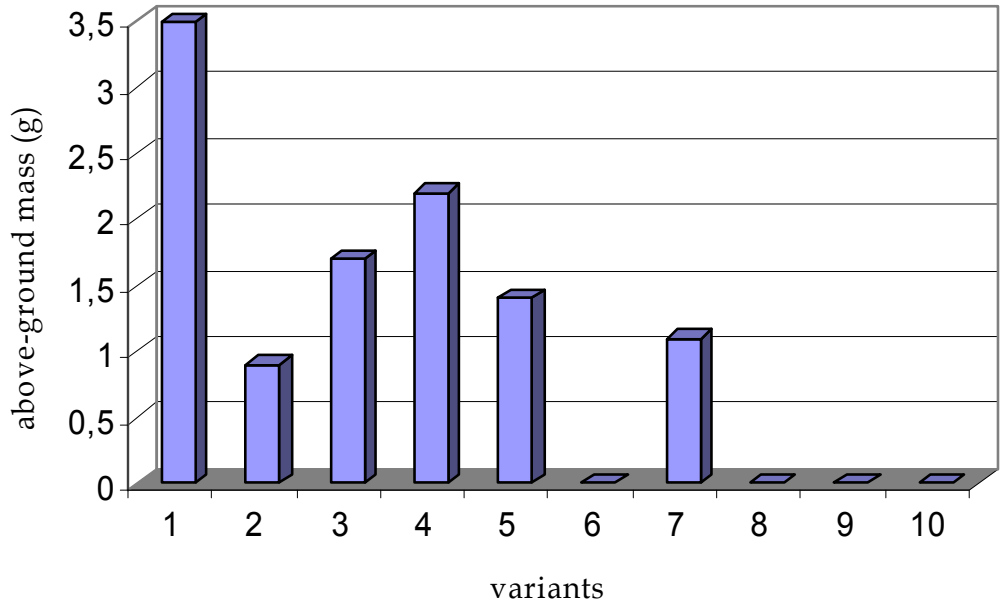

LSD $_{5 \%}-0,22,1 \%-0,30,0.1 \%-0,40$

Fig. 6. Effect of soil herbicides on the above-ground mass of peach seedlings (g). 
After application of napropamide (Var. 2), the strongest expression of the stem growth reduction in the seedlings was reported in comparison with the control. The differences were of high statistical significance.

There are data in literature about the response of some fruit species to soil herbicides when applying the sand culture method (Clay, 1984; Lourens, et al., 1989). Analogous results about the habits of peach seedlings after treatment with soil herbicides under sand culture conditions were obtained by Lourens, (1989). A slight phytotoxic effect was established after treatment of the experimental plants with pendimethalin, napropamide, oryzalin. The authors reported that even stronger phytotoxicity was observed after treatment with oxadiazon, alachlor, simazine.

The results obtained about the effect of the studied soil-applied herbicides on the vegetative habits of peach seedlings under sand culture conditions gave the grounds to draw the following conclusions: 1 . Growth habits closest to those in the control, were established in the plants treated with terbacil (Var. 4) and pendimethalin (Var. 3);

2. Strong phytotoxic effect on peach seedlings expressed in dying of the plants, was exerted by linuron, metolachlor, acetochlor and oxyfluorofen.

\subsubsection{Effect of soil-applied herbicides on the vegetative habits of wild cherry seedlings}

Strong phytotoxicity under sand culture conditions was established after treatment with all the tested herbicides, expressed in blocking of seed germination or dying of the emerged plants. That was the reason to conclude that wild cherry as a species is strongly susceptible to the effect of soil-applied herbicides under sand culture conditions.

In the model pot experiment on alluvial-meadow soil (Fluvisol), the plants of the variants tested with napropamide (Var. 2), pendimethalin (Var. 3) and isoxaflutole (Var. 7) emerged at the same time with those of the control. External symptoms of phytotoxicity were not observed in the seedlings treated with napropamide and pendimethalin.

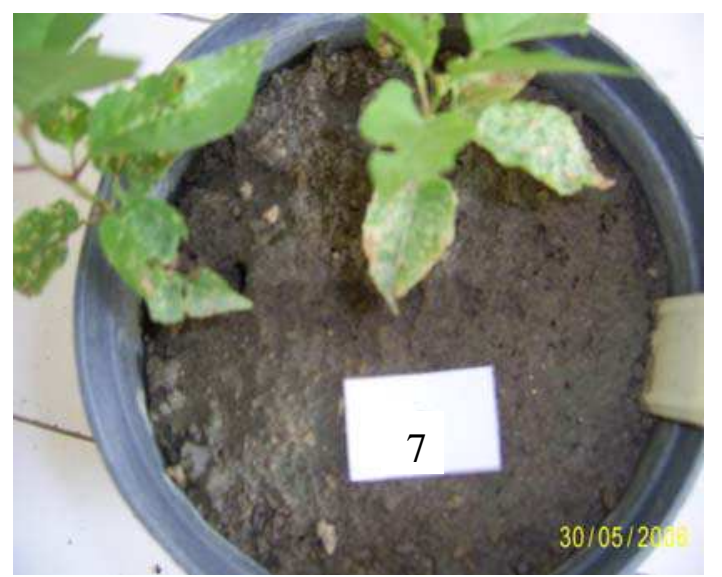

Fig. 7. White chlorosis in wild cherry seedlings after treatment with isoxaflutole (Var. 7)

After treatment with isoxaflutole (Var. 9), white chlorosis appeared in the leaves of the plants both along the leaf vein and between the leaf nerves. In those areas the chlorosis developed as white spots. Later (about a month) necrosis appeared in the white spots. 
At a later stage (about 40 days after plant emergence), those symptoms were not observed in the newly formed leaves. The leaves were fresh, green, without obvious suppression of plant growth. That was the reason to accept that the phytotoxicity of isoxaflutole in wild cherry seedlings was overcome in 40-60 days after emergence.

The seeds of the other variants treated with herbicides (Var. 4, 5, 6, 7 and 8) did not emerge or only single plants developed. Withering of the plant tip was observed, followed by dying of the plants in about 20 days after emergence. Consequently, the active substances terbacil, metolachlor, linuron, oxyfluorofen and oxadiargyl have a strong phytotoxic effect on wild cherry seedlings, causing the plant death.

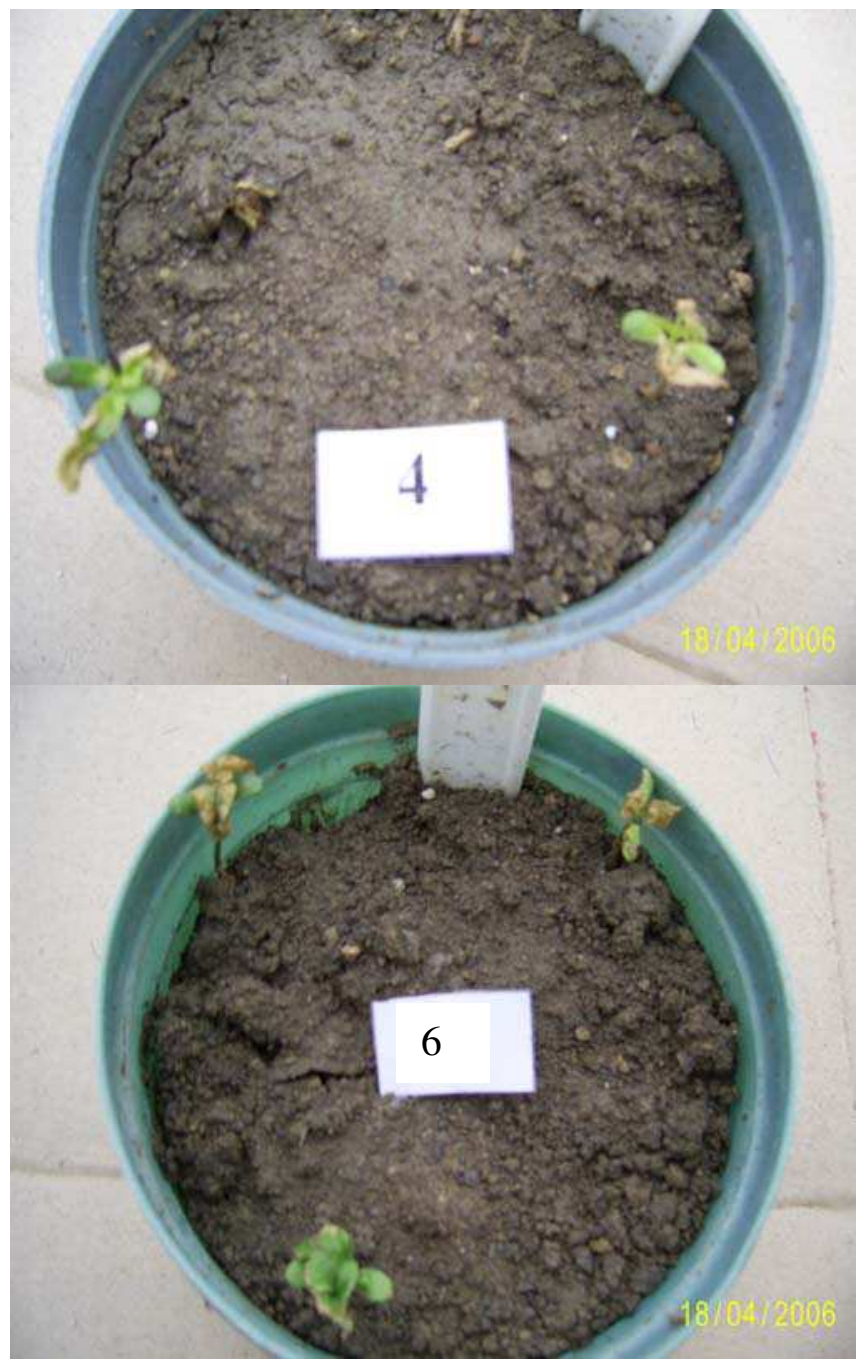

Fig. 8. Wild cherry seedlings with suppressed growth after treatment with terbacil (Var. 4) and metolachlor (Var. 6) 
The results of the biometric analysis showed different effects of the soil herbicides on the vegetative habits of the plants. The least inhibiting effect on stem growth in height was observed in the variants treated with napropamide (Var. 2) and isoxaflutole (Var. 9), (Fig. 9). The lowest height was reported for the plants treated with pendimethalin (Var. 3). The differences to the control were statistically significant. After the application of isoxaflutole (Var. 7) the values of plant height were close to those in the control.

The results about the effect of the applied herbicides on the above-ground mass of the plants were analogous with those of plant height (Fig. 10). The results obtained after treatment of the seedlings with napropamide and isoxaflutole again showed values close to the control. Again a depressing effect on that characteristic was reported in the variant with application of pendimethalin (Var. 3). The differences were statistically significant.

The results obtained about the effect of the soil-applied herbicides on the vegetative habits of wild cherry seedlings gave the grounds to draw the following conclusions:

1. Strong phytotoxicity expressed in blocking the seed germination and dying of the emerged plants was exhibited after applying the soil herbicides napropamide, pendimethalin, terbacil, metolachlor, linuron, acetochlor, oxyfluorofen, oxadiargyl and isoxaflutole at the tested rates under sand culture conditions.

2. Under the conditions of alluvial-meadow soil (Fluvisol), external symptoms of phytotoxicity and growth depression was not observed in seedlings after treatment with napropamide (Devrinol $4 \mathrm{~F}-400 \mathrm{ml} / \mathrm{da}$ ).

3. Application of isoxaflutole led to incidence of white chlorosis in the plant leaves, however phytotoxicity was overcome in about 40 days after treatment with the herbicide and no suppression of the vegetative habits were observed.

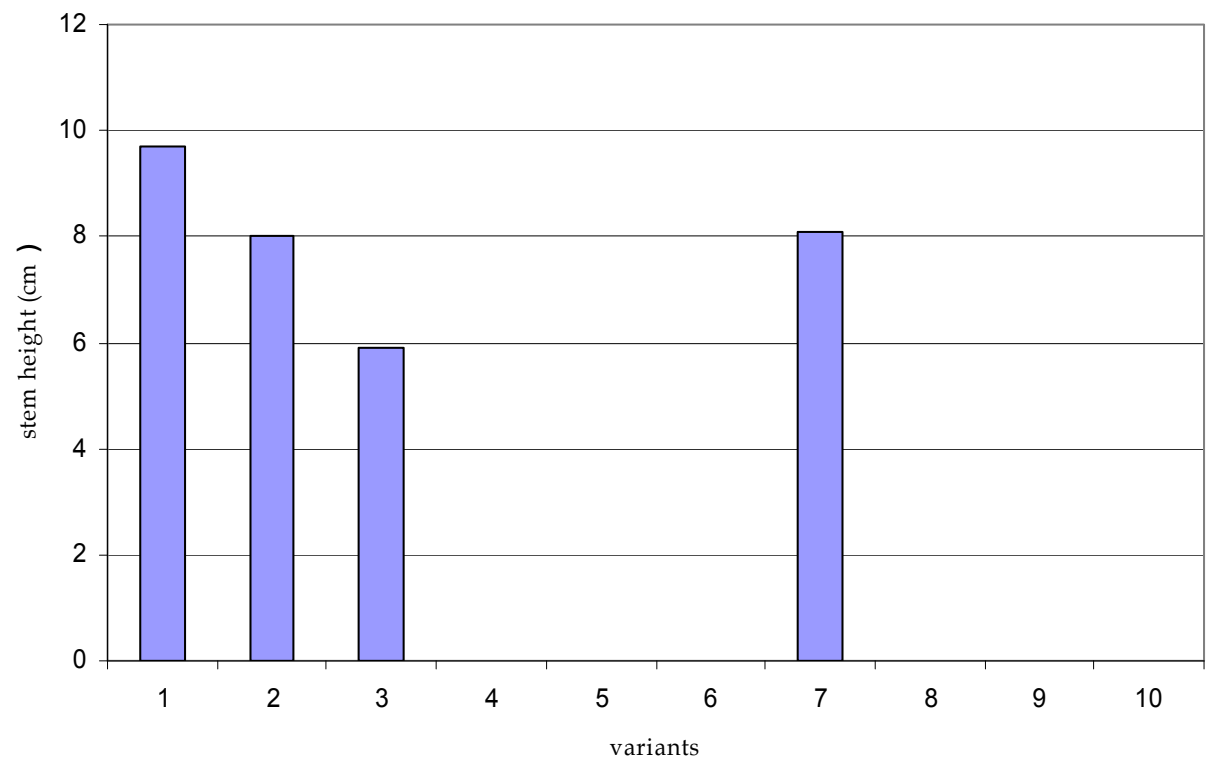

LSD $5 \%=1.87,1 \%=2.72,0,1 \%=4.07$

Fig. 9. Effect of soil herbicides on stem height $(\mathrm{cm})$ 


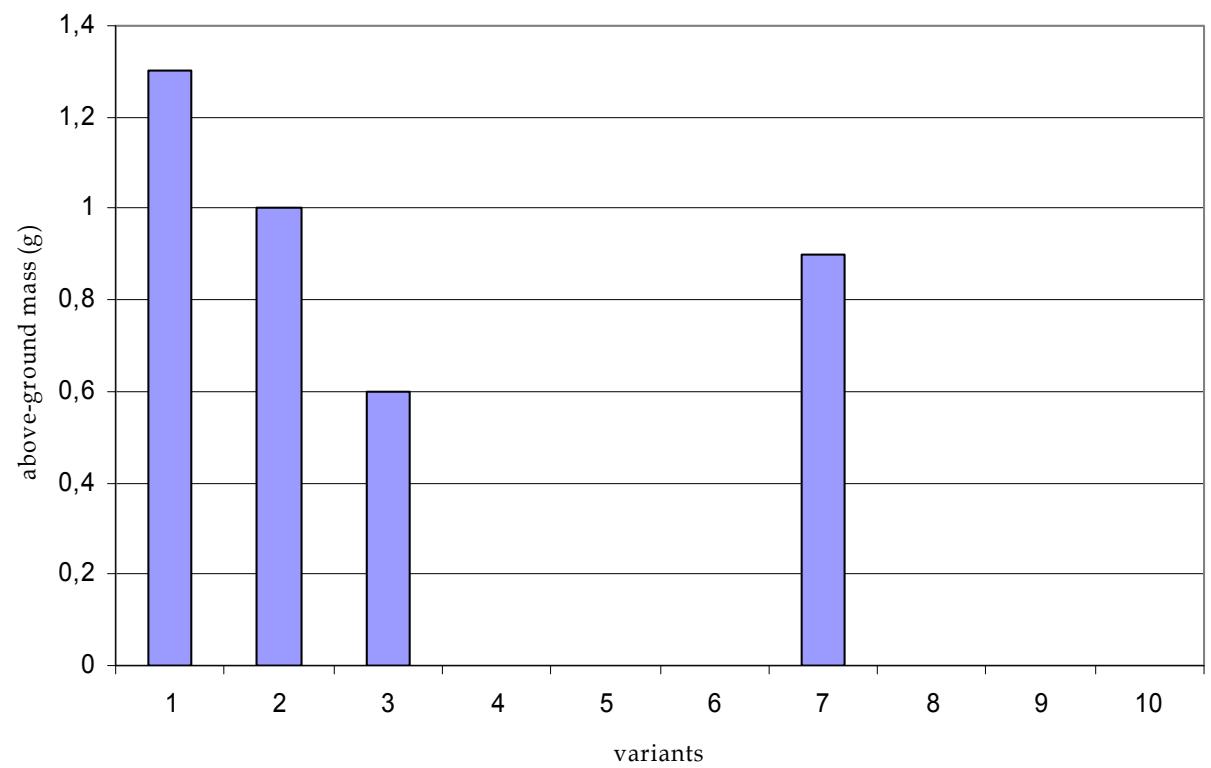

LSD $5 \%=0,36,1 \%=0,53,0,1 \%=0,80$

Fig. 10. Effect of soil herbicides on the above-ground plant mass (g)

4. Depressing effect on growth of wild cherry seedlings was established after treatment with pendimethalin - Stomp 33 EC - 4,0 1/ha.

5. Under the conditions of a model pot experiment on alluvial-meadow soil (Fluvisol) the active substances terbacil, metolachlor, linuron, acetochlor, oxyfluorofen and oxadiargyl had a strong phytotoxic effect on the seedlings, leading to plant death.

\subsection{Effect of the soil-applied herbicides on the vegetative habits of walnut seedlings \\ 2.3.1 Under sand culture conditions}

The seeds treated with napropamide (Var. 2), pendimethalin (Var. 3) and terbacil (Var. 4) emerged at the same time with those of the control. External symptoms of phytotoxicity were not observed. Later, delayed development of the seedlings was reported for the plants of the Variants 2 and 3.

Delayed emergence compared to the control was established for the plants treated with metolachlor (Var. 6), linuron (Var. 8) and oxyfluorofen (Var. 10). In Variant 6 only single plants emerged. An incidence of necrosis in their leaves was reported. The seedlings of the variants treated with metolachlor and oxyfluorofen died until the 20 th day after emergence. Similar symptoms of phytotoxicity were observed in the plants of Variant 8 - only single plants emerged and they had a seriously delayed development with necrosis at the margins of the apical leaves.

In the variants with application of oxadiargyl (Var. 10) and isoxaflutole (Var. 7) the seeds emerged at the same time as those of the control variant. External symptoms of phytotoxicity - chlorosis, necrosis, white chlorosis - typical of the species susceptible to isoxaflutole, were not observed. 
The results of the biometric analysis showed that the soil-applied herbicides had an effect expressed in different ways on growth and development of walnut seedlings. The plants of the variants treated with oxadiargyl and isoxaflutole (Var. 5 and 7) had a bigger stem height compared to the control (Fig. 11).

That was the reason to conclude that those two active substances do not exert a depressing effect on seedling growth. Values of the stem height, close to those in the control, were established in the plants treated with terbacil, napropamide and linuron (Var. 4, 2 and 8). Strong inhibiting effect under sand culture conditions was established in the plants treated with pendimethalin (Var. 3). The differences to the control were of high statistical significance. A similar effect of the soil-applied herbicides was observed on the other studied characteristic - the above-ground mass (Fig. 12). The plants treated with isoxaflutole (Var. 7) had a larger above-ground mass than those of the control variant. Consequently, the active substance isoxaflutole - Merlin $750 \mathrm{WG}$ at the rate $50 \mathrm{~g} / \mathrm{ha}$ did not suppress walnut seedling growth under sand culture conditions. A slighter depressing effect on that characteristic was established also in the plants treated with terbacil and linuron (Var. 4 and 8). The least above-ground mass was reported in the plants treated with pendimethalin (Var. 3) and napropamide (Var. 2). The differences to the control were again of high statistical significance.

Application of pendimethalin had a depressing effect on walnut seedling development under sand culture conditions. A similar result was observed in the other analogous studies about the effect of the soil-applied herbicides on the habits of peach and yellow plum seedling rootstocks.

The depressing effect of pendimethalin under sand culture conditions could be explained by the physical basis of the herbicide selectivity and the possibility to exhibit its phytotoxic effect on light soils (sand in the present case) and in a direct contact with the germinating seeds.

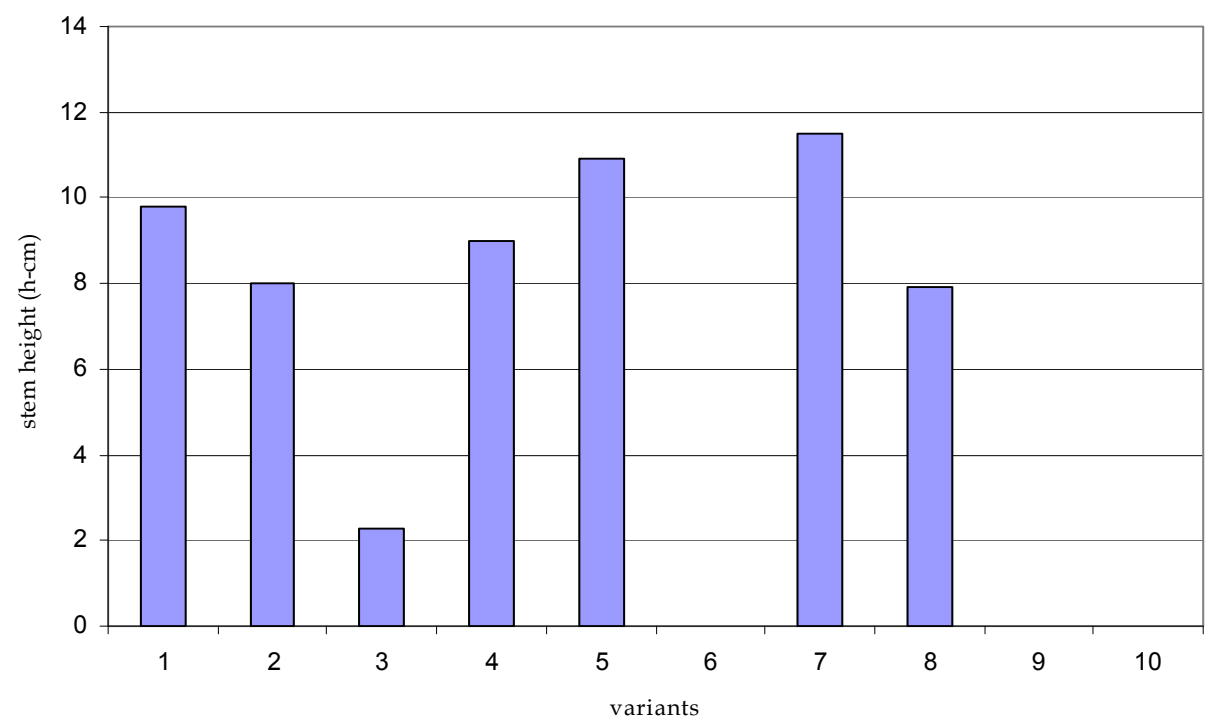

LSD 5\%-0,99, 1\%-1,36, 0,1\%-1,85

Fig. 11. Effect of soil herbicides on plant height $(\mathrm{h}-\mathrm{cm})$. 


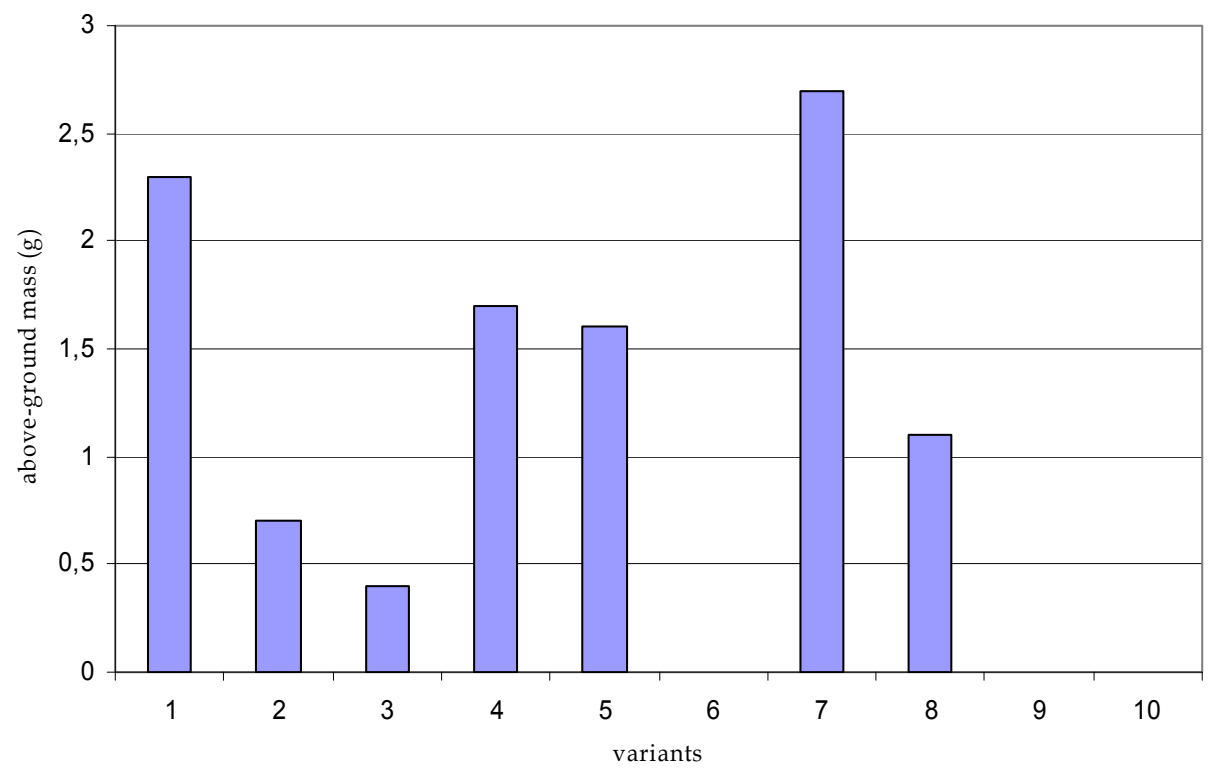

LSD $5 \%-0,32,1 \%-0,43,0,1 \%-0,59$

Fig. 12. Effect of soil herbicides on the above-ground mass (g).

\subsubsection{Under the conditions of a model pot experiment with alluvial-meadow soil (Fluvisol)}

Differences in the rate of emergence of the seedlings in the variants treated with herbicides and those in the control were not observed. External symptoms of toxicity (chlorosis, necrosis, withering of the stem or leaves) did not appear. Later a delayed development of the plants in the variants treated with pendimethalin (Var. 3), metolachlor (Var. 6) and oxyfluorofen (Var. 10) was established.

The results of the biometric analyses showed that the applied soil herbicides had a different effect on growth and development of the walnut seedlings. Plants of the variants treated with napropamide, terbacil, linuron and isoxaflutole (Var. 2, 4, 8 and 7) had a closer to stem height compared to the control (Fig. 13). The differences were not statistically significant.

A lower stem height was reported for the plants of the variants with applied pendimethalin, metolachlor, acetochlor and oxyfluorofen (Var. 3, 6, 9 and 10). That gave the grounds to accept that the application of those soil herbicides suppressed the stem growth of walnut seedlings.

Lower above-ground mass was reported in the plants of all the variants treated with herbicides (Fig. 14). The values of the plants in the variants treated with terbacil and isoxaflutole (Var. 4 and Var. 7) were the closest to the control.

The results about the depressing effect of the soil herbicides pendimethalin, metolachlor, and oxyfluorofen on that characteristic were analogous.

Therefore, it could be admitted that those soil herbicides had a depressing effect on the growth of walnut seedlings. 


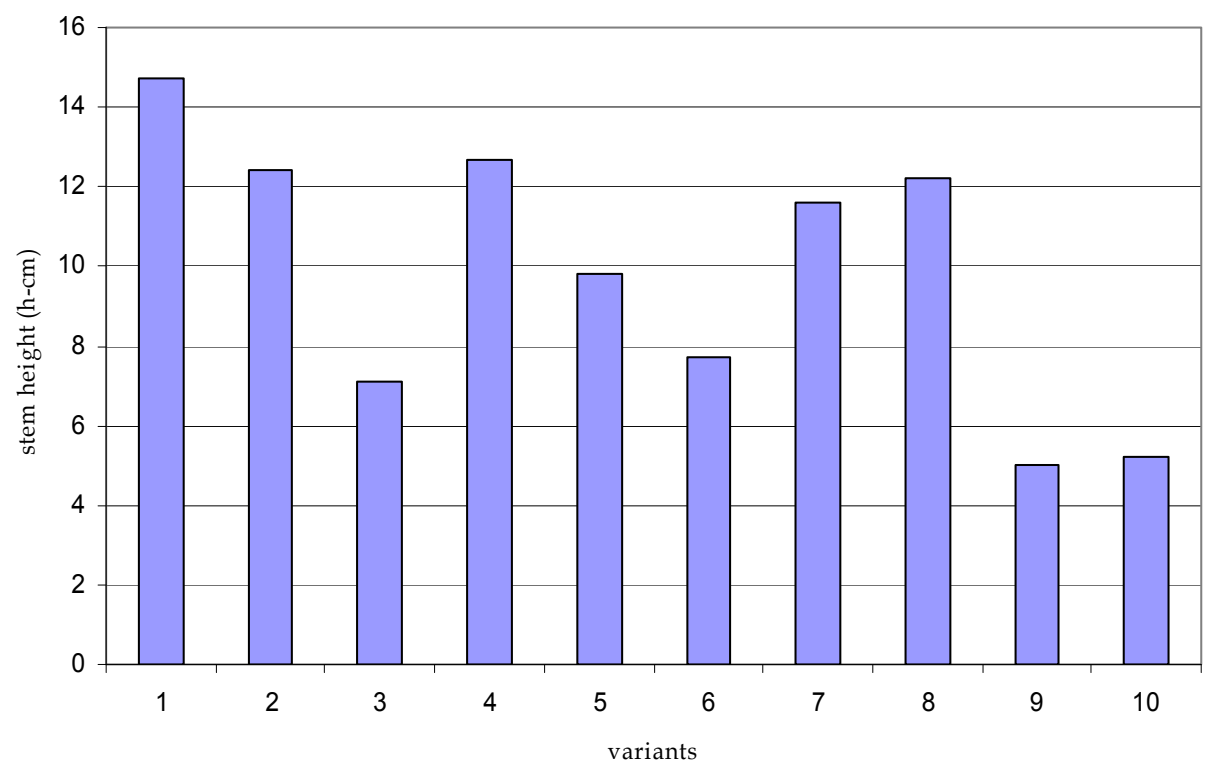

LSD $5 \%=4,44,1 \%=6,08,0,1 \%=8,28$

Fig. 13. Effect of soil herbicides on stem height of walnut seedlings $(\mathrm{h}-\mathrm{cm})$.

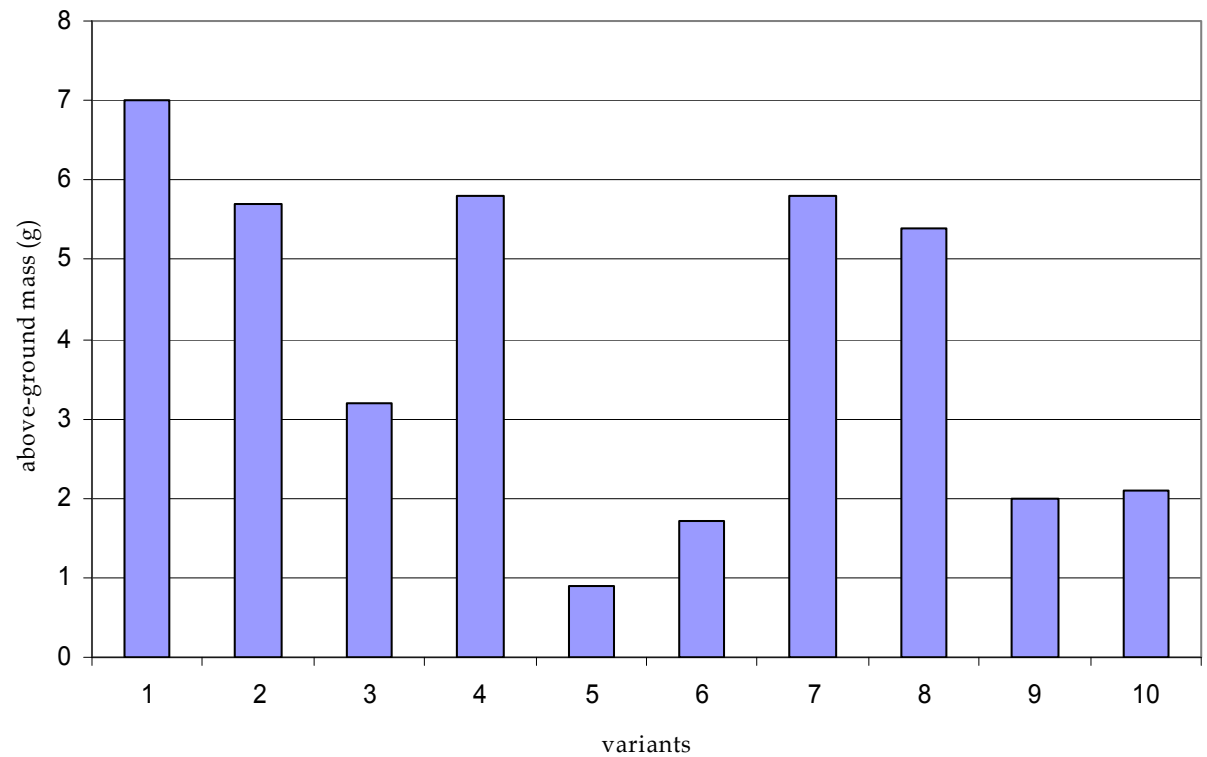

LSD $5 \%=1,51,1 \%=2,07,0,1 \%=2,81$

Fig. 14. Effect of soil herbicides on the above-ground plant mass (g) 
The following conclusions could be drawn from the results about the effect of the herbicides on the habits of walnut seedlings:

1. A depressing effect on walnut seedling growth, expressed in growth suppression and a significant decrease of the above-ground plant mass, was exerted after treatment with pendimethalin, metolachlor and oxyfluorofen.

2. After treatment with napropamide, terbacil, linuron and isoxaflutole no phytotoxic effect expressed in suppression of the vegetative habits of walnut seedlings was established.

\subsection{Effect of soil herbicides on the vegetative habits of apricot seedlings}

Plant habits under both conditions of the model experiment - under sand culture conditions and on alluvial-meadow soil (Fluvisol) were analogous at the initial stages of plant emergence and development.

The plants of the variants treated with herbicides (Var. 2, 3 and 4) emerged at the same time with those of the control. External symptoms of phytotoxicity - chlorosis, necrosis, as well as obvious disturbance of plant development, were not observed. Strong phytotoxicity expressed in an inability of the seeds to germinate or withering and drying of the emerged plants was established after treatment with the other herbicides included in the study (Var. 5-10).

The results of the biometric analysis showed that after treatment with terbacil (Sinbar $80 \mathrm{WP}$ $-1,0 \mathrm{~kg} / \mathrm{ha}$ ) the plants had a stem height close or bigger than those in the control variant. The differences to the control were statistically insignificant. Consequently, that active substance did not exert a depressing effect on stem growth (Fig. 15).

An inhibiting effect on growth was established after applying napropamide and pendimethalin under sand culture conditions. That could be explained by the mechanism of action of the active substances. It is known that napropamide stops the growth of the susceptible plants and pendimethalin inhibits cell division and elongation in the meristematic tissues of the stem (Tonev, 2000). Under sand culture conditions, when the effect of soil as a factor is eliminated, those characteristics of phytotoxicity in result of the herbicide application were much more obviously expressed. Under the conditions of alluvial-meadow soil, stem growth suppression was much weaker after applying those active substances. In that case the differences were insignificant.

The results obtained about the effect of the applied herbicides on stem weight were analogous (Fig. 16). A strong suppressing effect on that characteristic under sand culture conditions was established again after treatment with pendimethalin (Var. 3) and napropamide (Var. 2). That result could be explained by the effect of the active substances on seedling growth under the different conditions tested in the study. Under sand culture conditions the differences to the control were highly significant. Under the conditions of alluvial-meadow soil growth suppression of plant development was also reported after treatment with napropamide (Var. 2), however, in that case the inhibiting effect was much weaker.

The plants treated with terbacil under both experimental conditions had stem weight values close to that in the control. The differences to the control variant were statistically insignificant. That confirmed the results about the lack of phytotoxicity in the plants after applying Sinbar $80 \mathrm{WP}-1,0 \mathrm{~kg} / \mathrm{ha}$. 


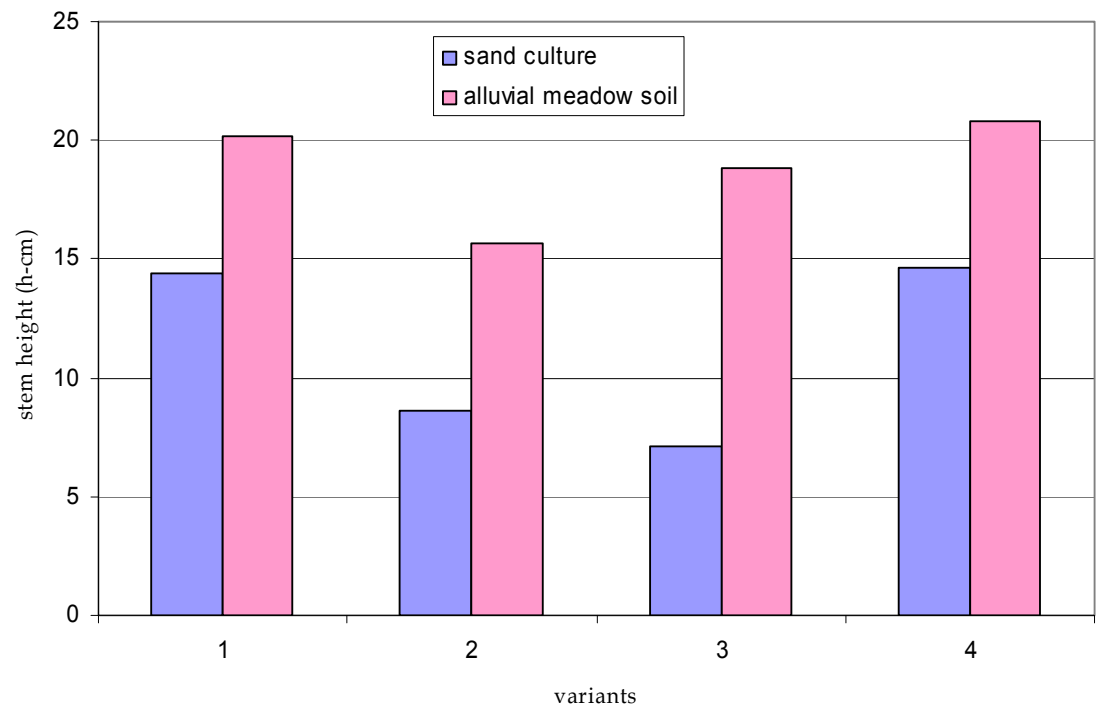

sand culture- LSD $5 \%=4,72$

alluvial meadow soil-n.s.

$1 \%=6,87$

$0,1 \%=10,31$

Fig. 15. Effect of soil herbicides on stem height $(\mathrm{cm})$.

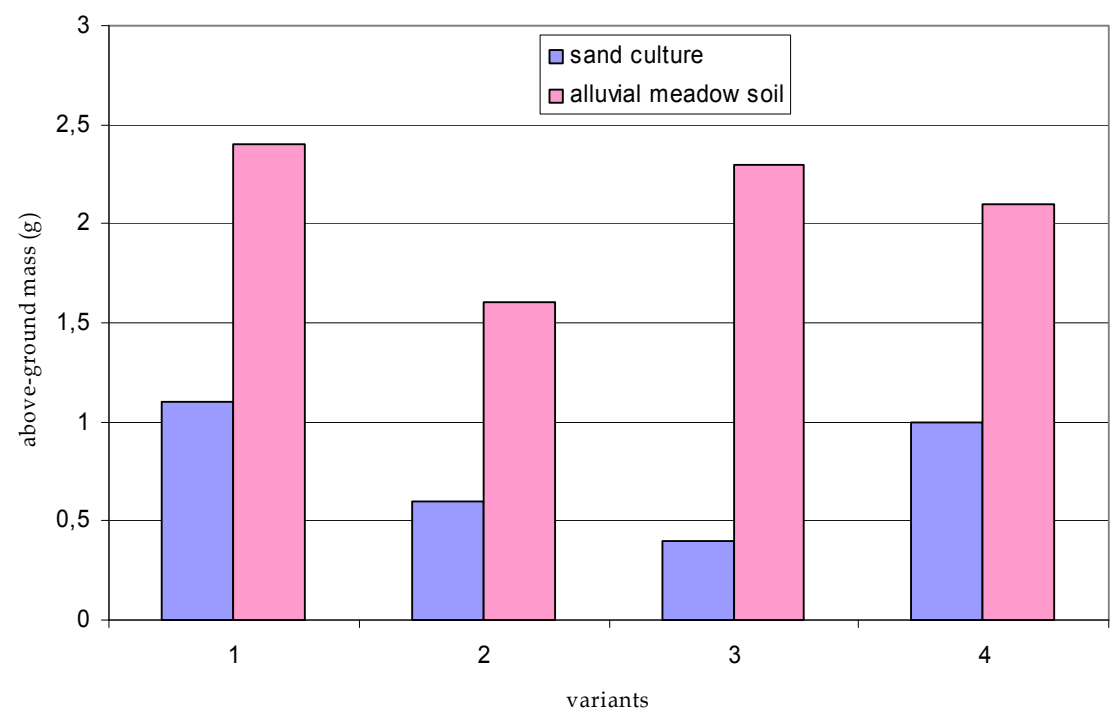

sand culture- LSD $5 \%=0.53$

alluvial meadow soil-n.s.

$$
\begin{array}{r}
1 \%=0.78 \\
0,1 \%=1.16
\end{array}
$$

Fig. 16. Effect of soil herbicides on above-ground mass (g). 
The results obtained gave the grounds to conclude that the application of terbacil, and pendimethalin under the conditions of alluvial-meadow soil did not cause phytotoxicity on apricot seedlings resulting in plant growth suppression. A negative effect on growth was established after treatment with napropamide. Similar results of phytotoxicity caused by napropamide under sand culture conditions were established in analogous studies with peach seedlings.

Under the conditions of alluvial-meadow soil, the effect of the herbicides was significantly weaker due to factors such as mechanical soil content, humus, $\mathrm{pH}$, argillaceous (loamy) fraction, etc. The conclusion could be drawn that when the stones are planted shallow in soils of a light mechanical composition and there is a direct contact between the active substance napropamide and the germinating seeds, then the incidence of phytotoxicity expressed in growth suppression is quite probable.

\subsection{Conclusions}

1. External symptoms of phytotoxicity were not established in apricot seedlings after treatment with napropamide, pendimethalin and terbacil.

2. Application of terbacil (Sinbar $80 \mathrm{WP}-1,0 \mathrm{~kg} / \mathrm{ha}$ ) did not cause suppression of growth habits in the seedlings.

3. Suppression of plant growth and development was established after treatment with napropamide - Devrinol 4 F - 4,0 1/ha under sand culture conditions.

The results obtained in the model studies showed that the sand culture method could be applied as a rapid model system for testing the habits of fruit species in response to the soilapplied herbicides. Under sand culture conditions the soil type (mechanical composition, humus) is eliminated as a factor affecting the plant habits and the soil herbicides and it is possible to obtain information about the response of the cultural fruit species to the different active substances.

\section{Field experiments for establishing the effect of some soil-applied herbicides on the vegetative habits of seedling rootstocks of yellow plum, peach and Mahaleb.}

\subsection{Material and methods}

The field studies were carried out on the experimental site on the territory of the FruitGrowing Institute - Plovdiv. The soil in the experimental plot was alluvial-meadow (Fluvisol), pH 7,4, with a good supply of phosphorus and potassium (Rankova, 2004,). Stratified seeds (stones) of yellow plum, peach and Mahaleb were planted in the period 15 25 March on an experimental plot of a size $1 \mathrm{~m}^{2}$ for each variant $\left(10\right.$ seeds per $\left.1 \mathrm{~m}^{2}\right)$ at $3-5 \mathrm{~cm}$ depth and 5-7 cm distance within the row. Immediately after planting the seeds, treatment with soil-applied herbicides was carried out. Four active substances of soil herbicides were used - napropamide, pendimethalin, terbacil and metolachlor, each of them used at three rates. The following variants were set: 1 . Control (untreated); 2 . Napropamide - Devrinol $4 \mathrm{~F}$ - 3,0 l/ha; 3. Napropamide - Devrinol 4 F - 4,0 l/ha; 4 . Napropamide - Devrinol 4 F - 5,0 1/ha; 5. Pendimethalin - Stomp 33 EC - 3,0 1/ha; 6. Pendimethalin - Stomp 33 EC - 4,0 1/ha; 7. Pendimethalin - Stomp 33 EC - 5,0 1/ ha; 8. Terbacil - Sinbar $80 \mathrm{WP}-750 \mathrm{~g} / \mathrm{ha}$; 9. Terbacil - Sinbar 80 WP - 1,0 kg/ha; 10. Terbacil - Sinbar 80 WP - 1,25 kg/ha; 11. Metolachlor - Dual Gold 960 EC - 1,125 1/ha; 12. Metolachlor - Dual Gold 960 EC - 1,5 1/ha; 13. Metolachlor Dual Gold 960 EC - 1,875 1/ha. 
The experiment was set by the standard chess-board method in 4 replications, the reporting area being $4 \mathrm{~m}^{2}$. The control was maintained free of weeds by three weedings out by hand by 30 -day intervals. During vegetation the rootstocks were grown following the standard technology.

Observations were made on plant growth and development during vegetation - emergence, external symptoms of phytotoxicity (chlorosis, necrosis, deformations of the plantlets).

In August (15-20 August) the rootstocks were qualified and the biometric characteristics stem height $(\mathrm{h}-\mathrm{cm})$ and thickness at the place of grafting $(\mathrm{mm})$, were reported. Plant qualifying at that period coincided with the time of grafting, determined as the most suitable for grafting in Bulgarian fruit-growing practice.

\subsection{Results and discussion}

\subsubsection{Effect of soil-applied herbicides on the vegetative habits of yellow plum seedling rootstocks}

The plants of all the variants treated with herbicides emerged at the same time as those of the control. External symptoms of phytotoxicity (chlorosis, necrosis, deformations of the plantlets) were not observed. Later a slight delay of growth was reported in all the three variants treated with different rates of metolachlor / Dual Gold $960 \mathrm{EC} /$. Growth depression was more obviously expressed in the variants of the medium and the high rates of metolachlor - Dual Gold 960 EC - 1,5 l/ha and 1,875 l/ha (Var. 12 and Var. 13).

The measured biometric characteristics - thickness at the place of grafting and plant height during vegetation showed the different effect of the herbicides applied to soil at the respective rates on growth and development of the yellow plum seedling rootstocks. The results obtained in the different years showed the same tendency and they were discussed as averaged values.

The results obtained about the thickness at the place of grafting showed that the plants treated with the herbicides napropamide, pendimethalin and terbacil applied at the three studied rates, had a larger thickness compared to the rootstocks in the control variant (Fig. 17). That could be explained by the efficient control on weed vegetation exerted by the applied rates of herbicides during the first three months of seedling vegetation and the eliminated competition of weeds for moisture, nutrient substances and light. It created suitable conditions for the successful emergence, growth and maturing of the rootstocks. Thus they reached the thickness at the place of grafting permitting their inoculation in the same year of their planting.

After treatment with the mentioned herbicides, values closest to the control were reported in the variant with the low rate of napropamide - Devrinol $4 \mathrm{~F}-3,0$ 1/ha (Var. 2) in all the three years of the study, which could be explained by the lower herbicide activity and efficiency against the weed vegetation. The differences were statistically insignificant $\operatorname{LSD}_{5 \%}=0,19$ (2001); 0,39 (2002); 0,32 (2003).

During the three study years the largest thickness at the place of grafting was reported in the rootstocks of Variant 9 (terbacil - Sinbar $80 \mathrm{WP}-1,0 \mathrm{~kg} / \mathrm{ha}$ ) - 7,3 mm, of Variant 6 (pendimethalin - Stomp $33 \mathrm{EC}-4,0$ l/ha) - 7,3 mm and of Variant 3 (napropamide Devrinol $4 \mathrm{~F}-4,0 \mathrm{l} / \mathrm{ha}$ ) - 7,2 $\mathrm{mm}$, versus 5,1 $\mathrm{mm}$ - the average thickness at the grafting zone in the control plants. Therefore, it could be admitted that the active substances napropamide, pendimethalin and terbacil applied at the tested rates, did not have a suppressing effect on growth and development of the seedlings. 


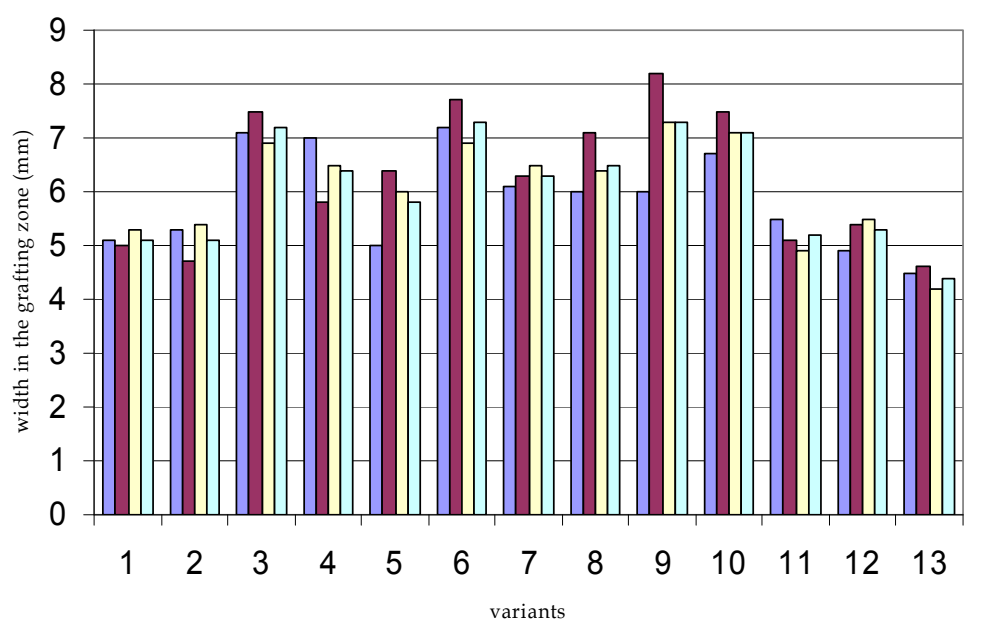

$\square 2001 \square 2002 \square 2003 \square$ in average for the period

$\operatorname{LDD}_{5} \%(2001)=0,19 ; \operatorname{LSD}_{1 \%}=0,25 ; \operatorname{LSD}_{0,1 \%}=0,32$

$\operatorname{LSD}_{5} \%(2002)=0,39 ; \operatorname{LSD}_{1 \%}=0,52 ; \operatorname{LSD}_{0,1 \%}=0,68$

$\operatorname{LSD}_{5} \%(2003)=0,32 ; \operatorname{LSD}_{1 \%}=0,42 ; \quad \operatorname{LSD}_{0,1 \%}=0,55$

Fig. 17. Thickness at the place of grafting $(\mathrm{mm})$ of the yellow plum seedling rootstocks in August

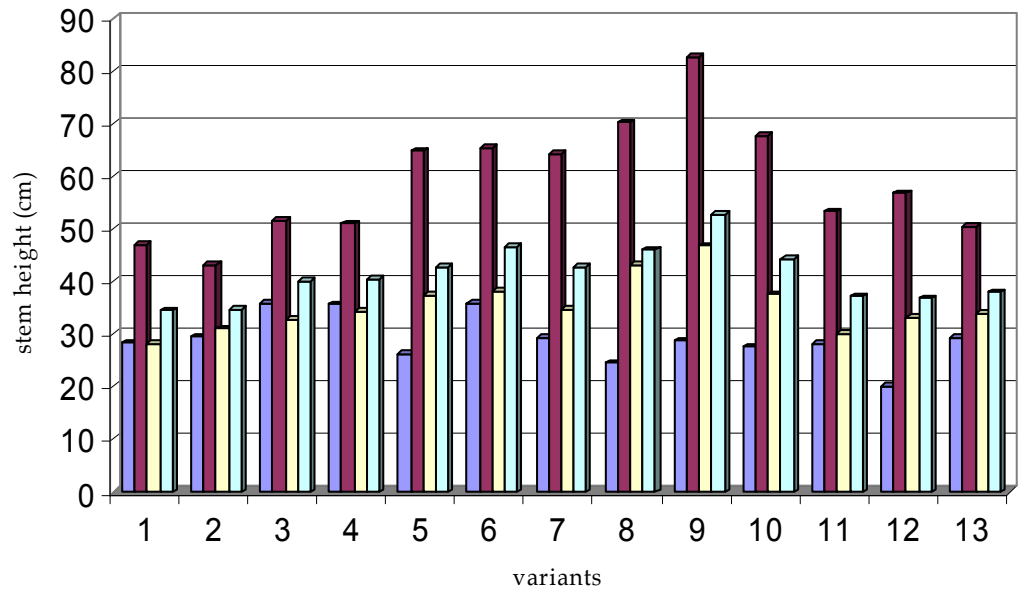

\section{$\square 2001 \square 2002 \square 2003 \square$ in average for the period}

$\mathrm{LSD}_{5} \%(2001$ г. $)=0,70 ; \operatorname{LSD}_{1 \%}=0,93 ; \operatorname{LSD}_{0,1 \%}=1,21$

$\mathrm{LSD}_{5} \%\left(2002\right.$ г.) $=3,83 ; \operatorname{LSD}_{1 \%}=5,10 ; \mathrm{LSD}_{0,1 \%}=6,63$

$\operatorname{LSD}_{5} \%(2003 \Gamma)=3,.60 ; \operatorname{LSD}_{1 \%}=4,78 ; \operatorname{LSD}_{0,1 \%}=6,22$

Fig. 18. Plant height $(\mathrm{cm})$ of the yellow plum seedling rootstocks 
With the increase of metolachlor rate, a tendency to a decrease of the thickness was observed (Var. 12-13).

That was also quite obviously expressed by the results about the effect of metolachlor on plant height, although the depressing effect of metolachlor on that characteristic was more weakly expressed. The obtained values were higher or close to those in the control (Fig. 18). In the three experimental years the highest values were obtained after applying the medium rate of: terbacil - Sinbar $80 \mathrm{WP}-1,0 \mathrm{~kg} / \mathrm{ha}-52,5 \mathrm{~cm}$ (Var. 9); pendimethalin - Stomp $33 \mathrm{EC}$ $-4,01 / \mathrm{ha}-46,5 \mathrm{~cm}$ (Var. 6) and the medium and the high rates of napropamide - Devrinol 4 $\mathrm{F}-4,0$ and 5,0 1/ ha $-40,0 \mathrm{~cm}$ and 40,3 cm (Var. 3 and Var. 4), the plant height in the control being $34,5 \mathrm{~cm}$.

In the experimental 2003, a variant with an unweeded and untreated control $\left(\mathrm{K}_{0}\right)$ was included in the study. Only single plants emerged in that variant, which were characterized by rather delayed development in result of the suppressing effect of the weed vegetation. When assessing their quality by reporting the stem height and thickness at the place of grafting, the advantages of the plants treated with herbicides were obvious - both concerning the quality of rootstocks and the number of the emerged seedlings (Fig. 19).

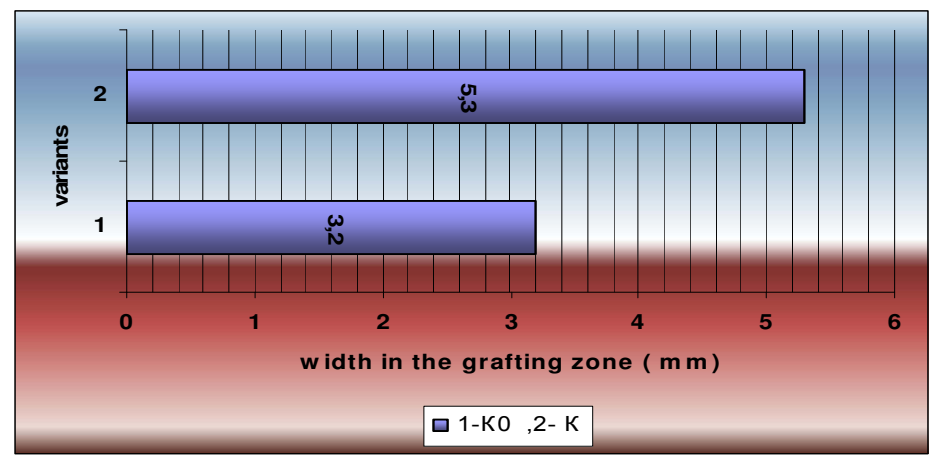

a)

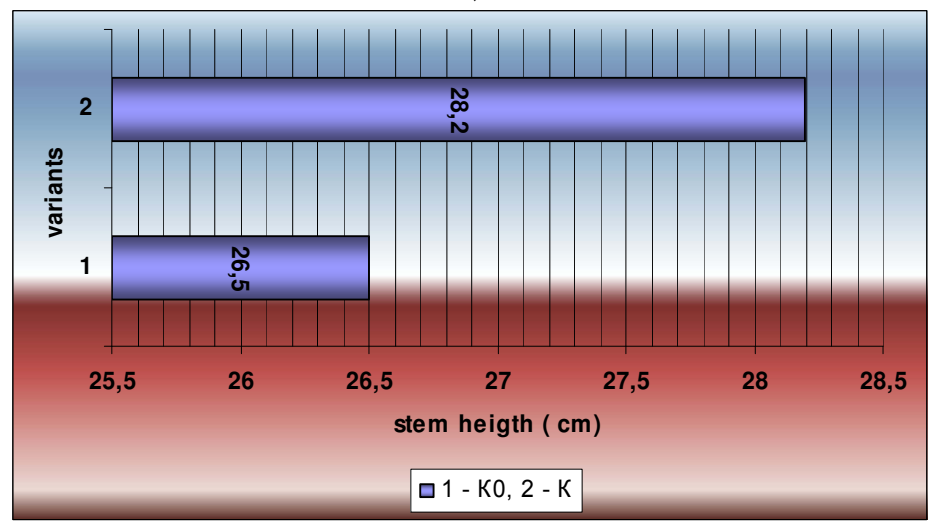

b)

Fig. 19. Yellow plum seedling rootstocks - comparison between unweeded $\left(\mathrm{K}_{0}\right)$ and weeded control $(\mathrm{K})$ in August: a/thickness at the place of grafting $(\mathrm{mm})$; b/ plant height $(\mathrm{cm})$ 


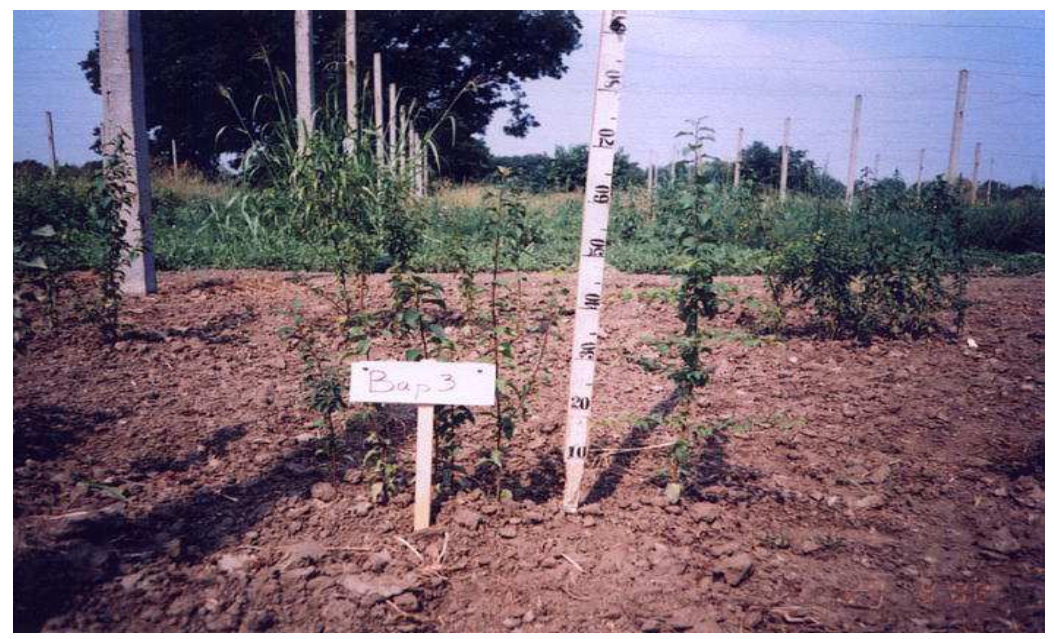

a)

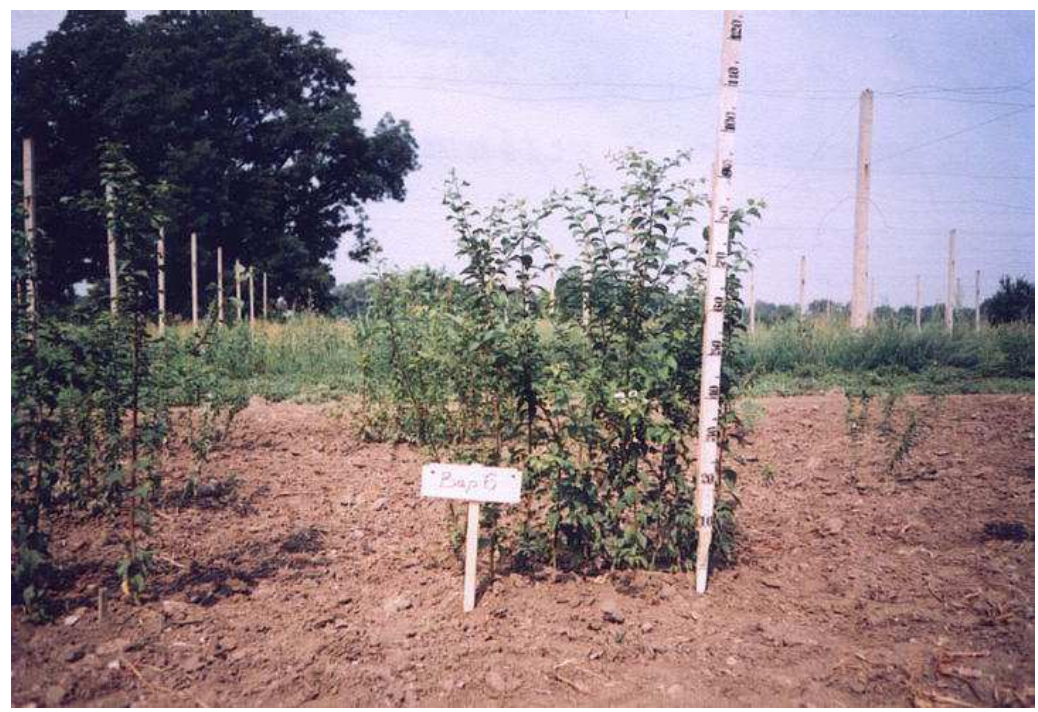

b)

Fig. 20. Yellow plum seedling rootstocks treated with: a) napropamid- Devrinol 4F-4.0 1/ha and b) pendimethalin - Stomp $33 \mathrm{EC}-4,01 /$ ha

It is clear that a good quality planting material without agrotechnical practices for control of the weed vegetation (weeding by hand) or chemical substances (herbicides) would not be possible to be produced. However, comparing plants grown under the conditions of strong natural weed infestation to those treated with herbicides, makes it possible to evaluate the advantages of the chemical means of weed control. It is quite obviously expressed when comparing the qualitative characteristics of the plants grown under the conditions of different weed infestation background - unweeded control, weeded control and variants 
with application of various rates of the respective soil herbicides. The measured thickness at the place of grafting in the rootstocks of the unweeded control $\left(\mathrm{K}_{0}\right)$ in August was small $3,2 \mathrm{~mm}$. It is obvious that planting material with such parameters of thickness at the place of grafting could not be inoculated in the year of seeding. Concerning the other characteristic plant height, the depressing effect of weed infestation was less expressed. That was probably due to the attempts of the seedlings to overcome the weed competition for light.

Significant changes in the content of leaf pigments (chlorophyll $a, b$ and $a+b$ ) and mineral elements in the leaves of the yellow plum seedling rootstocks were not established after treatment with the soil herbicides included in the study. There was a tendency to an increased content in the plants having higher values of the biometric characteristics (Rankova , 2004).

The following conclusions could be drawn from the results obtained about the effect of the soil-applied herbicides on the vegetative habits of yellow plum seedling rootstocks:

1. The following herbicides are recommended for realizing an efficient weed control in the production of planting material from yellow plum seeds: napropamide - Devrinol $4 \mathrm{~F}$ 4,0 l/ha, pendimethalin - Stomp $33 \mathrm{EC}-4,0 \mathrm{ml} / \mathrm{ha}$ and terbacil - Sinbar $80 \mathrm{WP}-1,0$ $\mathrm{kg} / \mathrm{ha}$.

2. After treatment of the seedling rootstocks with metolachlor - Dual Gold 960 EC, plant growth is suppressed. Consequently, the application of the active substance metolachlor should not be recommended in the integrated system of weed control in the production of yellow plum seedling rootstocks.

\subsubsection{Effect of the soil-applied herbicides on the vegetative habits of peach seedlings}

The plants of all the variants emerged simultaneously. External symptoms of phytotoxicity were not observed. Later a certain delay in plant growth and development was reported in the three variants treated with metolachlor - Dual Gold 960 EC (Var. 11 - 13). Growth suppression was very strong in the variant with the high rate of metolachlor - Dual Gold 960 EC - 1,875 1/ha (Var. 13), causing even the death of some plants.

The measured biometric characteristics in the middle of August showed the same tendency throughout the years of the study and they were discussed as averaged values. The data showed different effects of the soil-applied herbicides on rootstock development.

After treatment with the medium rates of napropamide - Devrinol $4 \mathrm{~F}-4,0 \mathrm{l}$ /ha (Var. 3), pendimethalin - Stomp $33 \mathrm{EC}$ - 4,0 1/ha (Var. 6) and terbacil - Sinbar $80 \mathrm{WP}-1,0 \mathrm{~kg} / \mathrm{ha}$ (Var. 9) the plants reached the highest values of thickness at the grafting zone $-7,0 \mathrm{~mm}, 7,2$ $\mathrm{mm}$ and 7,2 $\mathrm{mm}$, respectively (Fig. 21).

In all the three study years a lower value of thickness at the place of grafting was reported in the plants treated with metolachlor at the three applied rates (Var. 11 -12) compared to that in the control. That was probably due to the depressing effect of metolachlor on plant development. It was most strongly expressed after applying the high rate of Dual Gold 960 EC $-1,875$ 1/ha (Var. 13). Taking into consideration that rootstocks having a stem thickness of 4,0-4,2 $\mathrm{mm}$ are not suitable for inoculation, it can be concluded that the herbicide metolachlor has a depressing effect on the growth of peach seedlings.

The results about the effect of the soil herbicides on plant height showed that the values were lower in the plants treated with the low rate of napropamide - Devrinol $4 \mathrm{~F}-3,0$ 1/ha (Fig. 21).

That was observed in all the three years of the study and it was probably due to the weaker herbicide effect of the low rate of napropamide and the incidence of competition between 


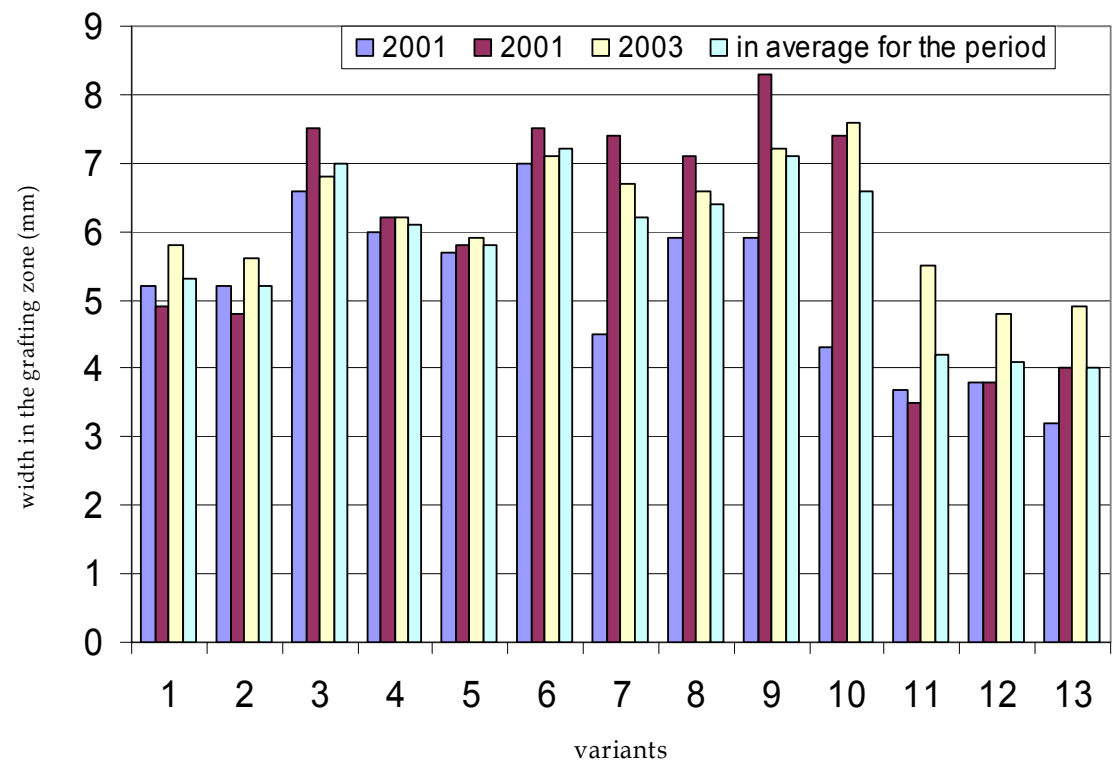

$\mathrm{LSD}_{5} \%(2001 \Gamma)=0,.15 ; \operatorname{LSD}_{1} \%=0,20 ; \operatorname{LSD}_{0,1 \%}=0,26$

$\mathrm{LSD}_{5} \%\left(2002\right.$ г.) $=0,38 ; \mathrm{LSD}_{1 \%}=0,50 ; \mathrm{LSD}_{0,1 \%}=0,75$

LSD $_{5} \%(2003$ г. $)=0,33 ; \operatorname{LSD}_{1 \%}=0,45 ; \operatorname{LSD}_{0,1 \%}=0,58$

Fig. 21. Thickness at the place of grafting $(\mathrm{mm})$ of peach seedling rootstocks

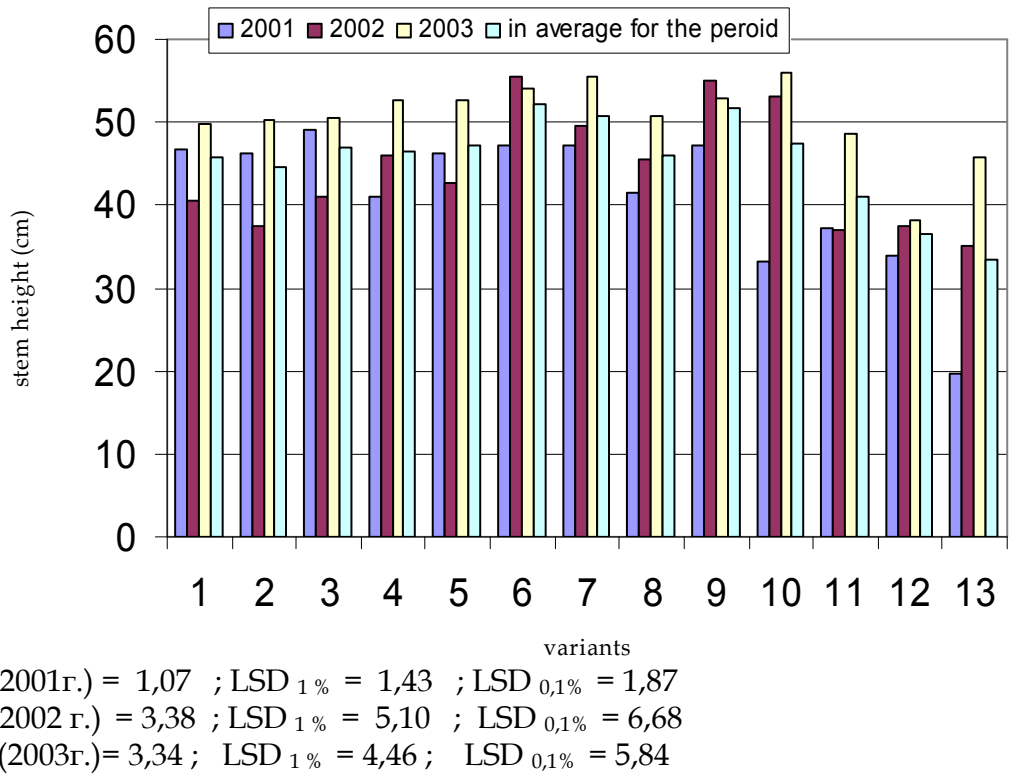

Fig. 22. Stem height $(\mathrm{cm})$ of peach seedling rootstocks. 
the seedlings and the developing weed vegetation for moisture and nutrient substances. However, the differences were statistically insignificant. Lower plant height was also reported for the plants of the variants treated with metolachlor at the three rates of Dual Gold 960 EC (Var. 11-13).

In average for the experimental period, it was most obviously expressed in the variant of the high rate of Dual Gold $960 \mathrm{EC}-1,875$ 1/ha (Var. 13) - 33,5 cm, the plant height in the control being $45,7 \mathrm{~cm}$. Those differences were significant or highly significant by years.

However, when discussing the average values of plant height for the whole period of study, the medium rates of the soil-applied herbicides proved to be optimal. The highest values of plant height were reported in the variants treated with pendimethalin - Stomp 33 EC - 4,0 1/ha (Var. 6) - 52,2 cm, terbacil - Sinbar $80 \mathrm{WP}-1,0 \mathrm{~kg} /$ ha (Var. 9) - 51,7 cm and napropamide - Devrinol 4 F - 4,0 1/ha (Var. 3) - 47,0 cm, the plant height of the control being $-45,7 \mathrm{~cm}$ (Fig. 32).

On the basis of the obtained results about the effect of the soil herbicides on the biometric characteristics established at the moment of grafting, it could be concluded that the active substances napropamide, pendimethalin and terbacil at the three applied rates did not exert a negative influence on growth and development of peach seedlings. Eliminating weed rootstock competition for moisture, nutrient substances and light in the first three months of seedling vegetation (the post-effect period of the applied herbicides) enables the production of plants suitable for grafting.

Significant changes in the content of chlorophyll and mineral elements in the leaves of the peach seedling rootstocks were not established after treatment with the soil herbicides included in the experiment. A tendency was established, similar to that in the yellow plum seedling rootstocks, that the content of chlorophyll and mineral elements increased in the plants having higher values of the biometric characteristics (Rankova, 2004).

In the experimental 2003, a variant with an unweeded and untreated control $\left(\mathrm{K}_{0}\right)$ was included in the study for establishing the effect of the soil-applied herbicides on growth habits of peach seedlings. In that variant only single plants emerged. They were characterized by a delayed growth and strongly suppressed development in result of the high competition of the weed vegetation for moisture, light and nutrients.

In August the rootstocks of that variant had 3,8 $\mathrm{mm}$ thickness at the place of grafting. Those rootstocks could not be grafted at that time (Fig. 23). The depressing effect of weed infestation had an obvious impact on the other characteristic - stem height (Fig. 23).

When comparing the qualitative characteristics of the rootstocks in that variant with the plants in the control weeded out by hand and the variants treated with herbicides, the results obtained in yellow plum rootstocks were confirmed. A good quality planting material suitable for grafting in the same year of seeding could not be produced without mechanical (weeding out by hand) or chemical methods of weed control. That shows the advantages of the chemical control of weeds in the production of peach seedling rootstocks.

1. The application of the following herbicides is recommended for the production of peach seedling rootstocks: pendimethalin - Stomp 33 EC - 4,0 1/ha, terbacil - Sinbar 80 WP $1,0 \mathrm{~g} / \mathrm{da}$ and napropamide - Devrinol $4 \mathrm{~F}-4,0$ l/ha.

2. Treatment with metolachlor showed an inhibiting effect on the growth habits of peach seedlings. The active substance metolachlor should not be applied for weed control in the production of peach seedling rootstocks. 


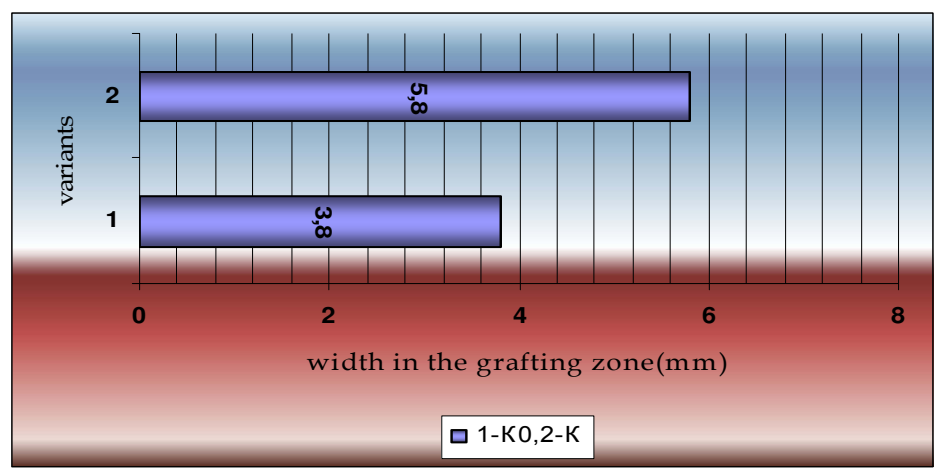

a)

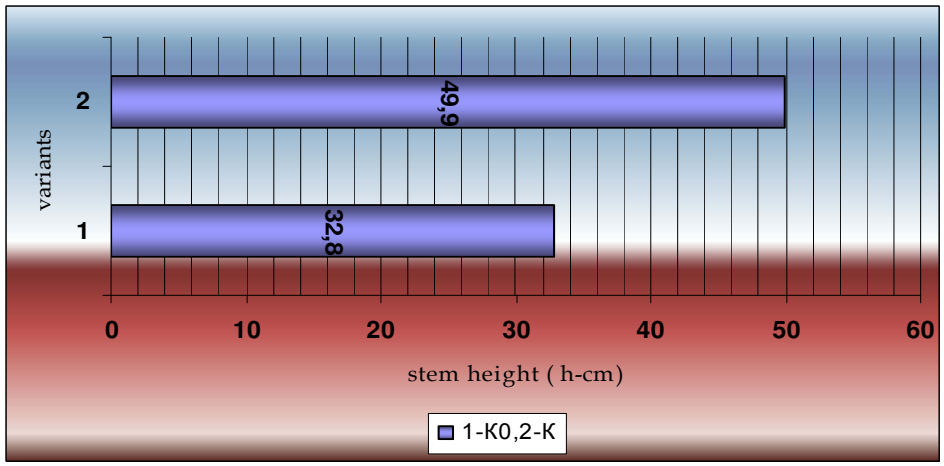

b)

Fig. 23. Peach seedling rootstocks - a comparison between unweeded control $\left(\mathrm{K}_{0}\right)$ and weeded out control $(\mathrm{K})$ in August: a/ thickness at the grafting zone $(\mathrm{mm}) ; \mathrm{b} /$ plant height $(\mathrm{cm})$

\subsubsection{Effect of soil-applied herbicides on the vegetative habits of Mahaleb seedlings}

Observations on the habits of Mahaleb seedlings treated with the soil-applied herbicides included in the study showed that they were highly susceptible to soil herbicides. Visual symptoms of phytotoxicity in the plants treated with napropamide, pendimethalin and metolachlor were not established. The seeds treated with those herbicides emerged at the same time as those in the control. Later, a certain delay in plant development was observed in the variant treated with the highest rate of metolachlor Dual Gold 960 EC - 1,875 1/ha (Var. 13).

In the three study years the plants treated with terbacil (Var. 8, 9, 10) responded in the same way - only single plants emerged and they had a very delayed development. Later chlorosis was detected, followed by withering and plant dying.

Consequently, it could be admitted that the soil herbicide terbacil was toxic for Mahaleb seedlings at all the three applied rates.

Data of the biometric analysis showed the same tendency throughout the years of the study and they were discussed as average values. 


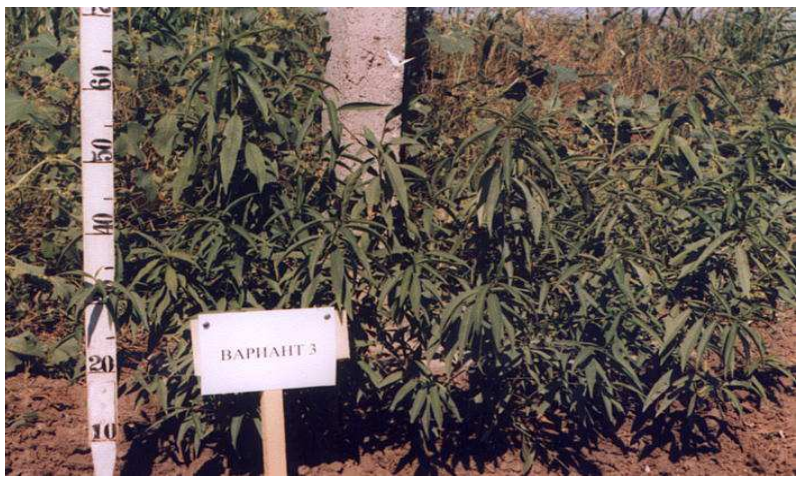

a)

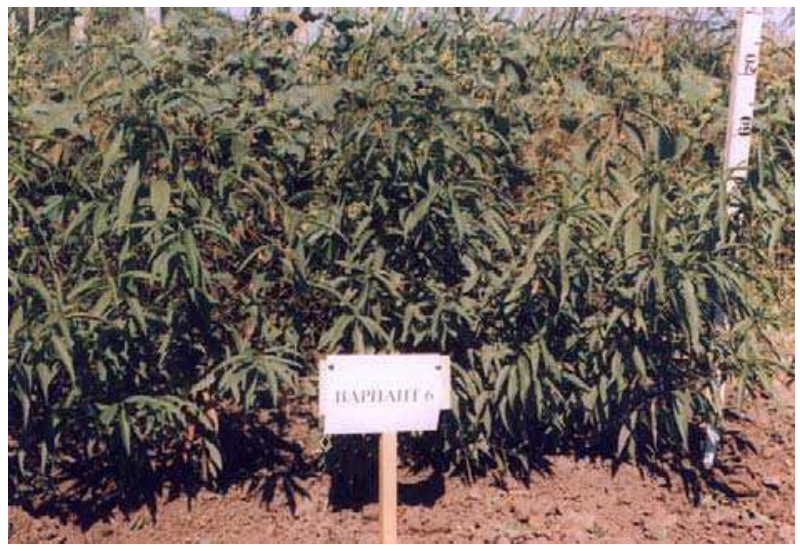

b)

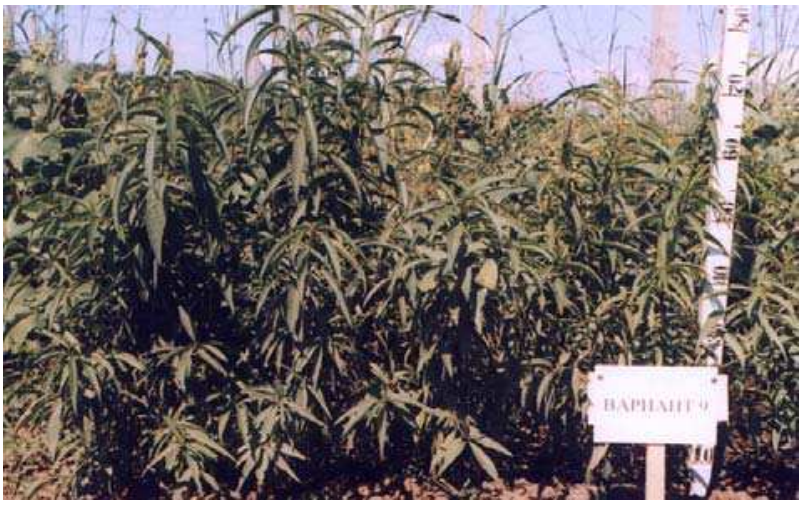

c)

Fig. 24. Peach seedling rootstocks treated with herbicides:

a) Var. 3 - napropamide - Devrinol 4 F - 4,0 l/ha; b) Var. 6 - pendimethalin - Stomp 33 EC 4,0 1/ha; c) Var. 9- terbacil - Sinbar $80 \mathrm{WP}$ - 1,0 kg/ha. 
The biggest value of stem thickness at the place of grafting was reported in the plants treated with pendimethalin - Stomp 33 EC - 4,0 1/ha (Var. 4 and 5) and metolachlor - Dual Gold 960 EC - 1,5 1/ha (Var. 12), (Fig. 25). The differences to the control were of high statistical significance.

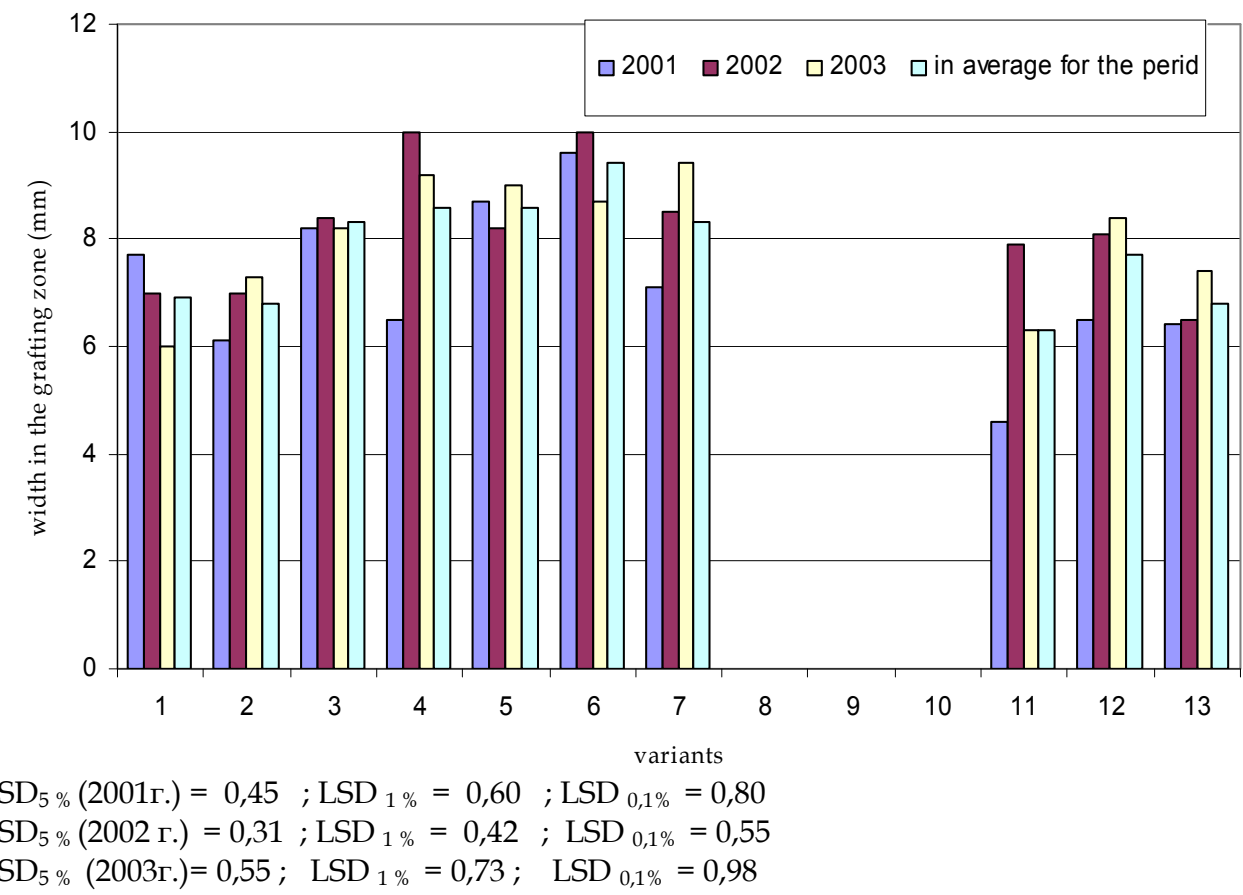

Fig. 25. Effect of soil-applied herbicides on thickness at the place of grafting $(\mathrm{mm})$ in Mahaleb seedling rootstocks

Similar to the results in yellow plum and peach seedling rootstocks, values of thickness close to the control were also established in the plants of the variant treated with the low rate of napropamide (Var. 2). However, the differences were statistically insignificant. That could be explained by the poorer efficiency of the lower herbicide rate and the existing weed-rootstock competition for moisture, nutrients and light. Probably, due to the same reasons, a smaller thickness was established in the plants treated with the low rate of metolachlor (Var. 11).

Values of that biometric characteristic were also lower in the plants of the variant treated with the highest rate of metolachlor - Dual Gold 960 EC - 1,875 1/ha (Var. 13). That was probably due to the depressing effect of the high rate of metolachlor on rootstock development.

The results about the effect of the soil-applied herbicides on plant height were analogous (Fig. 26).

The plants of the variants with applied napropamide (Var. 2 - 4), pendimethalin (Var. 5 - 7) and metolachlor (Var. 11 and 12) had a bigger height compared to those in the control. The differences were statistically significant. Values close to or lower than the control variant 
were established again in the plants of variants 2 and 13. Probably that was due to the already mentioned poorer herbicide efficiency of the low rate of napropamide and the existing competition with the weeds (Var. 2) and the exerted depressing effect of the high rate of metolachlor (Var. 13).

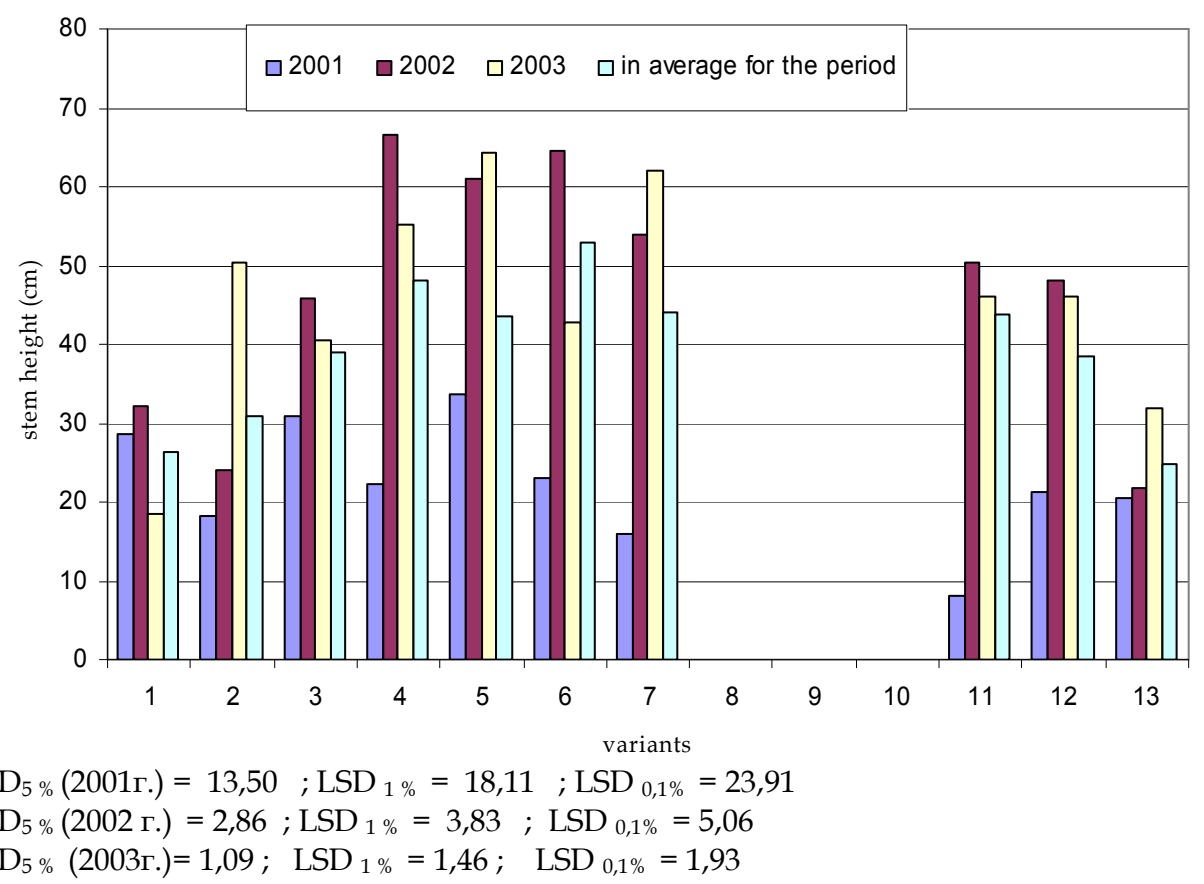

Fig. 26. Effect of soil herbicides on the height of Mahaleb seedling rootstocks $(\mathrm{cm})$

When including the variant with an unweeded control $\left(\mathrm{K}_{0}\right)$, all Mahaleb seedlings in that variant died in result of the strong competition with the weed vegetation.

Similar to the results obtained in the experiments with yellow plum and peach, significant changes in the content of chlorophyll and mineral elements in the leaves of Mahaleb seedling rootstocks were not established after treatment with the soil-applied herbicides included in the study. There was a tendency to an increase of their content in the plants having higher values of the biometric characteristics (Rankova, 2007).

\subsection{Conclusions}

1. The application of napropamide - Devrinol $4 \mathrm{~F}-4,0-5,0 \mathrm{l} / \mathrm{ha}$, pendimethalin - Stomp 33 EC - 4,0 l/ha and metolachlor - Dual Gold $960 \mathrm{EC} \mathrm{-} \mathrm{1,5} \mathrm{l/ha} \mathrm{is} \mathrm{recommended} \mathrm{in} \mathrm{the}$ production of Mahaleb seedling rootstocks.

2. The soil-applied herbicide terbacil (Sinbar $80 \mathrm{WP}$ ) had a strong toxic effect on Mahaleb seedling development and caused plant death.

3. The inhibiting effect of the soil herbicide metolachlor was exerted after treatment with the highest rate of Dual Gold 960 EC - 1,875 1/ ha. 


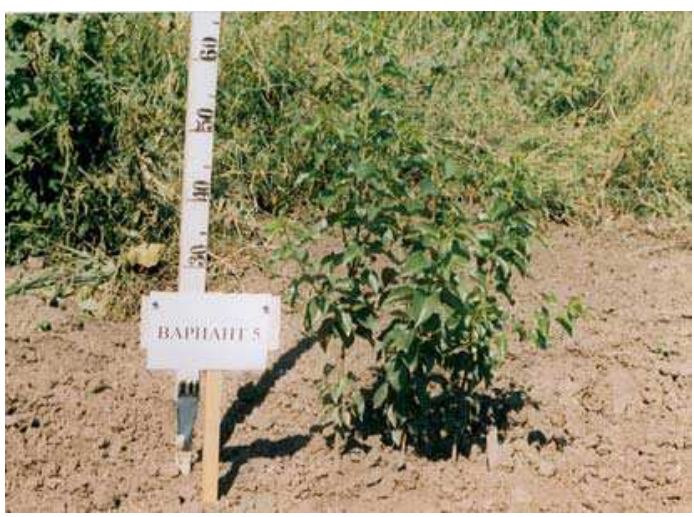

a)

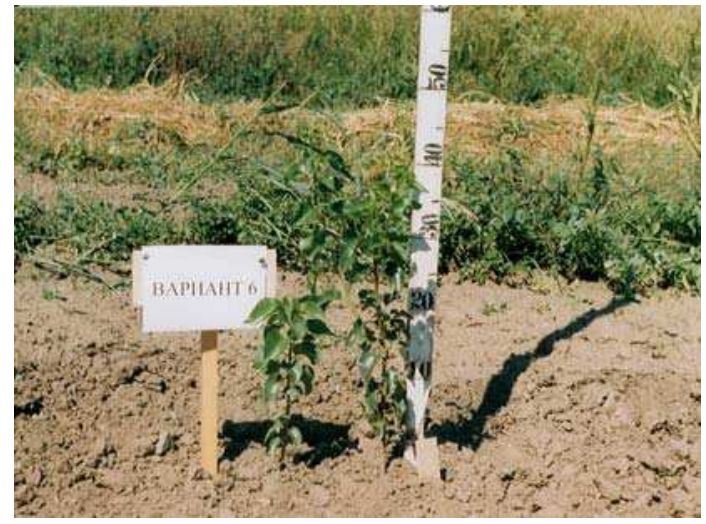

b)

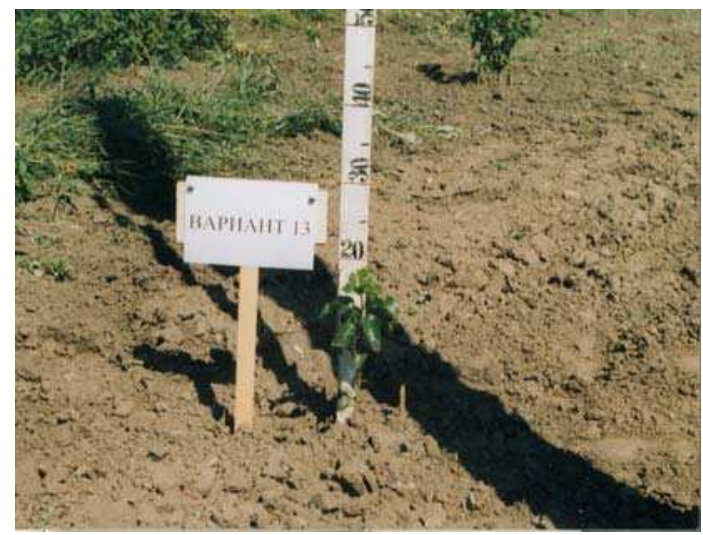

c)

Fig. 27. Mahaleb seedling rootstocks treated with: a) napropamide (Var. 5); b) pendimethalin (Var. 6) and c) metolachlor (Var. 13) 


\section{Discussion}

The results obtained from the pot and field experiments confirmed the initial assumption that the stone fruit species are susceptible to the application of soil herbicides. In the production of seedling rootstocks risky for causing phytotoxicity proved to be the probable direct contact between the germ of the emerging plant and the soil herbicide. In parallel with those studies, model experiments under in vitro conditions were carried out for phytotoxicity caused by soil herbicides. Using the ebryoculture method, the different effect of the soil-applied herbicide pendimethalin on the development of the embryo root of yellow plum embryos was established, depending on its initial length at the time of treatment (Gercheva, et al., 2001). Phytotoxicity (inhibition of root meristem growth and browning of cotyledons) was established in the treatment of embryos with embryonic roots $<5 \mathrm{~mm}$ in length. The embryos whose embryonic roots at the moment of herbicide application were longer than $5 \mathrm{~mm}$ did not show any symptoms of phytotoxicity (Fig.28). That allowed admitting that the selectivity of the active substance pendimethalin was of a physical character (a direct contact with the germinating seeds when they had been sown at a shallower depth) and of a physiological character (the type and the physiological stage of the plant development). Analogous results or results close to the model experiments with sand culture were obtained about the inhibiting effect or the lack of visual phytotoxicity of the soil herbicides napropamide, pendimethalin and terbacil under in vitro conditions in some vegetative rootstocks - GF-677, MM 106 and Wangenheims (Prunus domestica), (Rankova, et al., 2004; Rankova, et al., 2006a; Rankova, et al. , 2006b; Rankova, et al., 2009).

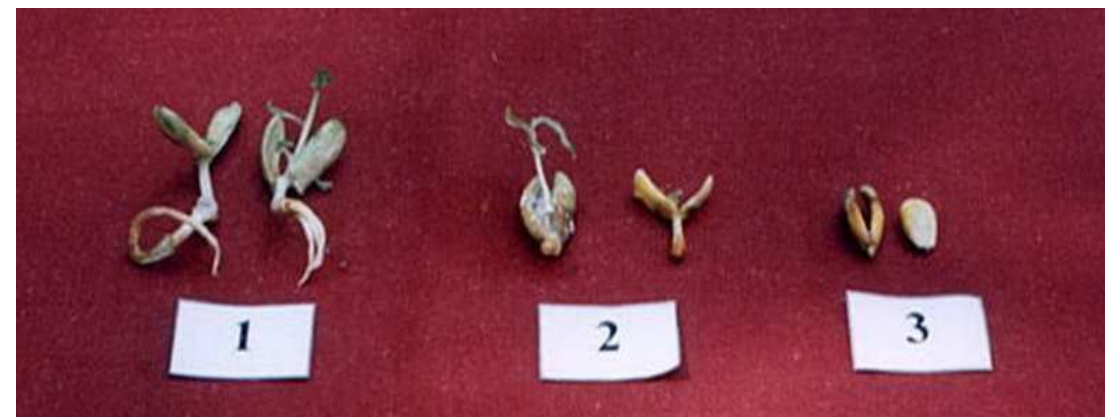

Fig. 28. Yellow plum embryos treated with pendimethalin

The results obtained from the field experiments allowed to accept the medium rates of napropamide - Devrinol 4 F - 4,0 1/ha, pendimethalin - Stomp 33 EC - 4,0 1/ha and terbacil - Sinbar $80 \mathrm{WP}-1,0 \mathrm{~kg} / \mathrm{ha}$ as suitable rates for applying in fruit nurseries in yellow plum and peach seedling rootstocks, on the one hand, and, napropamide - Devrinol $4 \mathrm{~F}-4,0-5,0$ 1/ha, pendimethalin - Stomp 33 EC - 4,0 1/ha and metolachlor - Dual Gold 960 EC - 1,5 1/ha - in Mahaleb seedlings. The highest values of biometric characteristics (thickness at the place of grafting and stem height) were reported in the plants of those variants. The major characteristic determining the planting material quality and its suitability for grafting is the thickness at the place of grafting. After treatment with herbicides applied at the rates mentioned, the highest values of the thickness at the place of grafting were obtained. That contributed to the production of high quality rootstocks suitable for inoculation in the year of seeding. The medium herbicide rates proved to be efficient against weed vegetation and they created good conditions for the development of the seedlings. It is known that 
eliminating the weed competition during the first three months of seedling vegetation (the period of seed emergence and the beginning of plant development) is a very important precondition for the normal growth and development of the plants. The results about the effect on the characteristics stem height and above-ground vegetative mass confirmed the incidence or the lack of a depressing effect on plant growth.

It is obvious that the low rates of the mentioned herbicides were less efficient against weed infestation. That was well expressed in the years of study under the conditions of higher weed density. The presence of weed plants in the plots of the variants treated with low rates created competition with the seedlings for moisture, light and nutrients. As a result of that lower values of the biometric characteristics were reported. Due to that only single cultural plants emerged with seriously delayed development in the variant of unweeded and untreated control.

In the variants with the high rates of napropamide (Var. 4), pendimethalin (Var. 7) and terbacil (Var. 10) the herbicide efficiency was also very well expressed. The differences in the values of the rootstock biometric characteristics in those variants compared to the values in the variants with the medium rates were small and statistically insignificant in most cases. External symptoms of phytotoxicity were not observed.

Metolachlor applied at the three rates had a suppressing effect on the growth habits of both the yellow plum and peach seedling rootstocks. That was quite obviously expressed when applying the high rate.

The results reported about the effect of the studied herbicides on growth habits of seedling rootstocks confirmed the results about the effect of some active substances obtained by other authors- (Hogue, 1983) established that napropamide $(4 \mathrm{~kg} / \mathrm{ha})$ and the herbicide mixture napropamide + terbacil $(4+2 \mathrm{~kg} / \mathrm{ha})$ were not toxic and did not cause disturbances in the development of peach seedlings. After treatment with trifluralin $(1 \mathrm{~kg} / \mathrm{ha})$ referring to the group of nitroanilines, to which pendimethalin also belongs, no toxic effect on peach seedlings was established, as well. Strong toxicity of peach seedlings was observed after treatment with metolachlor $(1,7-6,8 \mathrm{~kg} / \mathrm{ha})$ - suppression in seed emergence and growth disturbances were reported.

When comparing the responses of the seedling rootstocks of the three species, it could be concluded that the herbicide effect was weaker when treating yellow plum seeds (stones). Probably the good germination capacity of the yellow plum seeds and their easier adaptability to the soil and climatic conditions contributed to their much easier overcoming of the herbicide stress effect.

Comparing the bahaviour of Mahaleb seedlings to that of the seedling rootstocks of other fruit species allowed concluding that Prunus mahaleb L. species is more susceptible to the applied soil herbicides compared to yellow plum and peach. Similar habits were obtained after applying napropamide and pendimethalin at the studied rates, showing a lack of phytotoxicity in the rootstocks. A depressing effect of the active substance metolachlor in Mahaleb plants was established only after treatment with the highest rate of Dual Gold 960 EC (Var. 13).

The economic analysis of the chemical control of weeds in fruit nurseries showed that the application of herbicides in the production of yellow plum and peach seedling rootstocks led to 16 - 36 times higher return on investment and the efficiency coefficient was from 14 to 43 times higher compared to hand weeding out. Data about the economic effect of applying herbicides in the production of Mahaleb seedling rootstocks were similar - from 12 to 27 times higher return on investment and from 14 to 30 times higher efficiency coefficient in comparison with hand weeding out (Manolova \& Rankova, 2005; Manolova \& Rankova, 2007). 
The recommended soil herbicides (with an exception of terbacil, which is prohibited for use nowadays) have about a three-month period of persistency, weak water solubility and they do not carry the risk of soil and ground water pollution with residues (Tonev, 2000). Due to the fact that usually soils of a light mechanical composition are used for establishing fruit nurseries - alluvial, alluvial-meadow, characterized by their weak absorption capacity - the risk of polluting such soils with residual amounts of herbicides was minimal (Bakalivanov, 1980). There are data that the herbicides recommended for application in fruit nurseries do not have an inhibiting effect on soil microflora (Bakalivanov, 1980). Consequently, their application does not have a negative effect on the biological activity of soil.

In conclusion, it should be mentioned that weed control in fruit nurseries should be carried out on the basis of a sound knowledge about the response of the separate rootstock species to the applied soil herbicides, looking for the point of intersection of the herbicide rate, so that it is efficient enough against the weeds and selective to the cultural plant. Thus, a good quality planting material for establishing new fruit orchards will be produced.

\section{References}

Abdul, B., Mohammad, K. \& Tasleem, J. (1998): The effect of chemical weed control in peach nursery on germination and seedling growth. Sarhad Journal of Agriculture, 14, 1, pp. 43-47.

Arenstein ,Z. (1980). The control of annual weeds in young and matute orchards by means by terbutryne and terbutryne/simazine mixture. British crop protection conference of weeds, Nottingam, Proceedings, 1, pp. $159-163$.

Bakalivanov, D.(1980). Soil- microbiological aspects on herbicide contamination. Institute of soil science"Nikola Poushkarov'-Sofia, pp. 254

Clay, D. V.( 1984). Evaluation of the tolerance of cheery and plum trees to root application of herbicide using a sand culture method. Aspects of applied biology. Assoc of applied biologist, 8 , pp. $75-86$.

Hogue E. (1983). Weed control in peach seedlings. Exp. Committee on weeds. Western Canada Section, Res. Rep., 3, pp. 145 - 146.

Jankovic, R., Stanojevic, V.\& Rakicevic M. (1995): Herbicides in nursery tree production. Jugoslovensko Vocarstvo, 29, 1-2, pp. 93-101.

Gercheva, P., Rankova, Z. \& Ivanova, K. (2002). In vitro Test System for Herbicide Phytotoxicity on Mature Embryos of Fruit Species, Acta Horticulturae, 577, ISSN 0567-7572, pp. 333-336.

Kaufman, E.\& Libek, A. (2000a). The application of herbicides in a fruit - tree nursery. Proceedings of the International Conference Fruit Production and Fruit Breeding, Tartu, Estonia,: 61-64.

Kaufman, E.\& Libek, A. (2000b). Damages to cherry plum seedlings (Prunus cerasifera var. Daviricata Bailey ) caused by herbicides. Proceedings of the International Conference Fruit Production and Fruit Breeding, Tartu, Estonia, pp. 132-137.

Lange, A.H.(1987). Comparative phytotoxicity studies in trees and vines. Proceedings 39 th annual California weed conference,pp. $210-212$.

Lourens ,A.F.; Lange, A. \& Calitz, F. (1989). Phytotoxicity of pre- emergence herbicides to peach seedlings (Prunus persica ). South African Journal of plant and soil, 6 , 2 , pp. 97 $-102$.

Manolova, V. \& Rankova,Z. (2005). Economic results of using herbicides in the production of some seedling rootstoks, Bulgarian Journal of Agricultural Science, 2, pp. 159-163 
Manolova, V. \& Rankova, Z (2007). Comparative economic evaluation of herbicide use in the production of Prunus mahaleb seedling rootstocks. Agricultural Economics and Managements, 52, 2, pp. 56-58

Milusheva, Sn.\& Rankova.Z. (2002). Plum pox poty virus Detection in Weed Species under Field Conditions. Acta Horticulturae, 577, ISSN 0567-7572, pp. 283 - 287.

Milusheva, Sn. \& Rankova.Z. (2006). Serological Identification of Plum Pox Virus in some economic important weeds. Agricultural Science , ISSN 1313-3534, 4, 38-41

Mitchell, R.B.\& Abernethy, R.J. (1989). The effect of weed removal on the growth of young apricot trees. Proc.40 th New Zealand Weed and Pest control conf. Nelson, Aug.11-13, Palmerston North, pp. 209 -212.

Oosten, Van H.J. (1971). Futher information about herbaceous host range of sharka /Plum pox/. Ann. Phytopathologie, pp. $195-201$.

Porterfield J.D., Odell J.D. \& G.R. Huffman (1993). Effects of DCPA/ napropamide herbicide tank mix on germinants of seven hardwood species in tree nursery beds. Tree Planters Notes, 44, 4, pp. 149-153.

Rankova, Z. \& Milusheva, Sn.(2001). Problems with the weed plants in the epidemiology of Plum Pox Virus. Fifth Scientific Practical conference "Ecological problems of Agriculture" AGROEKO 2001,Agricultural University-Plovdiv, Scientific Works, vol. XLVI, book1,pp. 381-384

Rankova, Z. (2002). Effect of some soil herbicides on growth habits of peach seedlings (Persica vulgaris L.) under the conditions of sand culture. Proceedings of Papers from the Fourth Scientific and Technical Conference with International Participation "ECOLOGY AND HEALTH 2002", pp. 75-80.

Rankova, Z. (2004). Study on the effect of some soil herbicides on the vegetative habits of yellow plum and peach seedling rootstocks, $P h D$ Thesis.,fruit growing Institute- Plovdiv, pp.156

Rankova, Z. , Gercheva, P. \& Ivanova K. (2004). Screening of soil herbicides under in vitro conditions, Acta Agriculturae Serbica, vol. IX, 17,pp. 11-17

Rankova, Z(.2006). Effect of some soil herbicides on the vegetative habits of mahaleb cherry (Prunus machaleb L.) seedling rootstocks, Bulgarian Journal of Agricultural Science, 12,pp. 429-433

Rankova, Z., Nacheva L., Zapryanova K., Gercheva P. \& Bozkova, V.(2006a). Effect of soil herbicides napropamid and pendimethalin on rooting and growth of the vegetative plum rootstock Pr. domestica Wangenheims under in vitro conditions. Journal of mountain agriculture on the Balkans, 9(3), pp. 349-359.

Rankova, Z., Nacheva L., Gercheva P, \& Bozkova V.,(2006b). Vegetative habits of plum rootstock Wangenheims after treatment with terbacil under in vitro conditions. VI National Conference "Ecology and helth" Plovdiv, May 2006 pp. 339-344.

Rankova, Z (2007). Mineral composition and chlorophyll content in the leaf mass of mahaleb seedling rootstocks (Prunus mahaleb L.) after the application of some soil herbicides. International scientific Conference-Plant Genetic Stoks-The basis of Agriculture of today. 1314 June 2007, Sadovo, ISBN 978-954-517-083-6, 2 ,pp. 599-601

Rankova, Z., Nacheva, L. \& Gercheva P. (2009). Growth Habits of the Vegetative Apple Rootstock MM 106 After Treatment With Some Soil Herbicides Under In Vitro Conditions, Acta Horticulturae 825, ISSN 0567-7572, pp. 49-54

Tonev, T. (2000). Handbook of integrated weed control and culture of farming, Book 2, Higher Institute of Agriculture, Plovdiv, pp.275, pp 126-127

Wazbinska, J. (1997). Technological improvement of generative cherry plum rootstocks, oneyear Wegierka Lowicka plum trees and apple seedlings. Acta. Academiae Agriculturae ac Technicae, Olstenensis Agricultura, 64 c, pp. 107. 


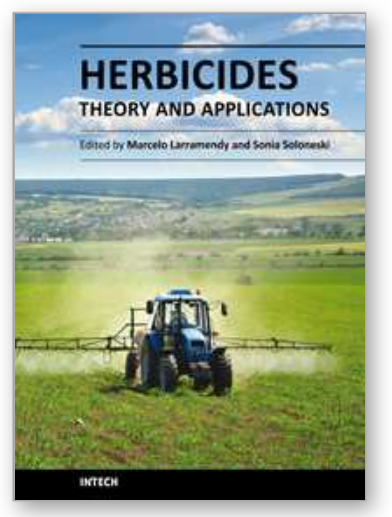

\author{
Herbicides, Theory and Applications \\ Edited by Prof. Marcelo Larramendy
}

ISBN 978-953-307-975-2

Hard cover, 610 pages

Publisher InTech

Published online 08, January, 2011

Published in print edition January, 2011

The content selected in Herbicides, Theory and Applications is intended to provide researchers, producers and consumers of herbicides an overview of the latest scientific achievements. Although we are dealing with many diverse and different topics, we have tried to compile this "raw material" into three major sections in search of clarity and order - Weed Control and Crop Management, Analytical Techniques of Herbicide Detection and Herbicide Toxicity and Further Applications. The editors hope that this book will continue to meet the expectations and needs of all interested in the methodology of use of herbicides, weed control as well as problems related to its use, abuse and misuse.

\title{
How to reference
}

In order to correctly reference this scholarly work, feel free to copy and paste the following:

Zarya Rankova (2011). Possibilities of Applying Soil Herbicides in Fruit Nurseries - Phytotoxicity and Selectivity, Herbicides, Theory and Applications, Prof. Marcelo Larramendy (Ed.), ISBN: 978-953-307-975-2, InTech, Available from: http://www.intechopen.com/books/herbicides-theory-and-applications/possibilities-ofapplying-soil-herbicides-in-fruit-nurseries-phytotoxicity-and-selectivity

\section{INTECH}

open science | open minds

\section{InTech Europe}

University Campus STeP Ri

Slavka Krautzeka 83/A

51000 Rijeka, Croatia

Phone: +385 (51) 770447

Fax: +385 (51) 686166

www.intechopen.com

\section{InTech China}

Unit 405, Office Block, Hotel Equatorial Shanghai

No.65, Yan An Road (West), Shanghai, 200040, China

中国上海市延安西路65号上海国际贵都大饭店办公楼405单元

Phone: +86-21-62489820

Fax: $+86-21-62489821$ 
(C) 2011 The Author(s). Licensee IntechOpen. This chapter is distributed under the terms of the Creative Commons Attribution-NonCommercialShareAlike-3.0 License, which permits use, distribution and reproduction for non-commercial purposes, provided the original is properly cited and derivative works building on this content are distributed under the same license. 